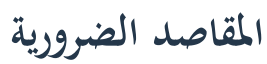

\section{بين مبدأ الحصر ودعوى التغير}

* عبد النور بزا

مقدمة

إن دعوى مراجعة حصر المقاصد الضرورية في المقاصد الخمسة المشهورة قديمة التداول في الدرس الأصولي المقاصدي، لكنها ما زالت بحاجة إلى المزيد من المراجعة والتحرير. وقبل النظر في هذه الدعوى، يجدر بي أن أشير ابتداء إلى أن "الإشكال" ليس في كون هذا المقصد أو ذاك مقصداً شرعياً، وإنما هو : هل هذا المقصدُ هرئ

الشرعيُّ أو ذاك مقصدُ شرعيٌّ ضروريٌُّ أوْ لا؟

فهذا هو الإشكال الذي نرومُ الاجتهادَ في تجديد النظر فيه، وترير القول بشأنه بقدر الإمكان؛ إذْ "معرفة

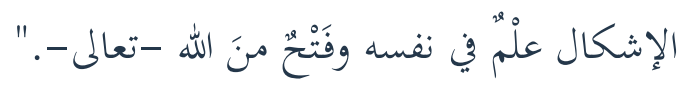

وقد تَصَدَّتْْ هذه الورقةُ لمذا الإشكال من خلال معالجة مُمْجَزَةٍ لماهية المقاصد الضروريّة وأدلتها ومعاييرها، وبيان بجمل الإضافات المقاصدية القديمة ومراجعتها، وبيان بجمل الإضافات المقاصدية الحديثة ومراجعتها.

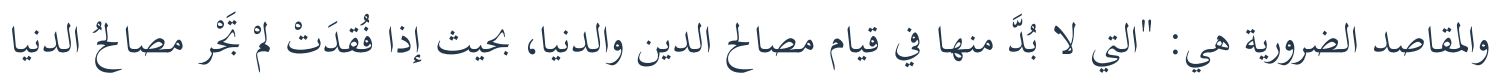
على استقامةٍ بلْ على فسادٍ ومَارُجٍ وفَوْت حياةٍ وفي الأخرى فوتُ النجاة والنعيم والرجوعُ بالخسران المبين ". وبهذا يظهر أن المقاصد الضرورية أساس نظام الشريعة والحياة، بحيث إذا أُقيمَتْ الحاكميةُ الإلهيةُ، واستمرَّتُ الحياةُ البشريةُ. وإذا اختلَّتُ اختلَّ نظامُ العمران، وفني الإنسان، وشقي يوم القيامة. ولذلك لا يمكن الاستغناء عنها أبداً؛ لأن جميع المصالح الدنيوية والأخروية ترتبط بها وتدور عليها وجوداً وعدماً. ف"مصالح الدين والدنيا مبنية على المحافظة على الأمور الخمسة المذكورة فيما تقدم، لذا اعتبر قيام هذا الوجود الدنيوي مبنيا عليها، فإذا الخرمت لم يبق للدنيا وجود -أعني ما هو خاص بالمكلفين والتكليف- وكذلك الأمور الأخروية، لا قيام لها إلا بذلك." وإِذْ وَضُحَتْ ماهيةُ المقاصد الضرورية فإلى النظر في أدلتها . 
إن المقاصد الضرورية لا بحد أدلة تأصيلها في آيات القصاص والحدود وأحاديثهما فقط كما ظن البعض، بل بحد تأصيلها في ثلاثة أدلة، وهي: النَّصُّ، والعقلُ، والواقع.

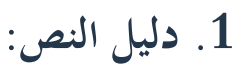
أما دليل النص فهو الدليل الشرعي الأول يُمََّّاً في الكتاب والسنة والإجماع، كما قال الإمام الغزالي:" مقاصدُ الشرع تُعْرَفُ بالكتاب والسنة والإجماع، فكلُُ مصلحةٍ لا ترجعُ إلى حفْظ مقصودٍ فُهمَ منَ الكتاب والسنة

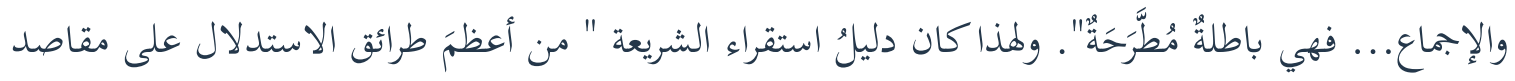
الشريعة." وقد اعتمده الإمام الشاطبي في تأصيل قصد الشارع في وضع الشريعة ابتداء، وفي تأصيل المقاصد الضرورية خاصة .

وقد عبََّر عن تأصيل قصد الشارع بقوله:" كون الشارع قاصداً للمحافظة على القواعد الثلاث: الضروريّة، والحاجيّة، والتحسينيّة، لا بُدَّ عليه من دليلٍ يستندُ إليه، والمستند إليه في ذلك، إما أن يكون دليلا ظنيا أو دليلا قطعيا. وكونُهُ ظنياً باطلُ، مع أنه أصلٌٌ من أصول الشريعة، بل هو أصلُ أصوها. وأصولُ الشريعة قطعيةٌ، فأصولُ أصولها أولى أن تكون قطعيةً. ولو جاز إثباها بالظن لكانت الشريعة مظنونةً: أصلاً، وفَرْعَاً، وهذا باطلّ. فلا بد أن تكون قطعية، فأدلتها قطعية بلا بد. ودليل ذلك استقراء الشريعة، والنظر في أدلتها الكلية والجزئية وما انطوت عليه من هذه الأمور العامة على حد الاستقراء المعنويّ الذي لا يثبت بدليل خاص، بل بأدلة منضاف بعضها إلى بعض، مختلفة الأغراض، بجيث ينتم من بجموعها أمر واحد بتجتمع عليه تلك الأدلة... فلم يعتمد الناس (العلماء) في إثبات قصد الشارع في هذه القواعد على دليل مخصوص، ولا على وجه مخصوص، بل حصل لمم ذلك من: الظواهر، والعمومات، والمطلقات، والمقيدات، والجزئيات الخاصة في أعيان مختلفة، ووقائع مختلفة، في كل باب من أبواب الفقه، وكل نوع من أنواعه، حتى ألفوا أدلة الشريعة كلها دائرة على تلك القواعد. هذا مع ما ينضاف إلى ذلك من قرائن أحوال منقولة وغير منقولة ". وأما تأصيل المقاصد الضرورية خاصة فقد عبر عنه قائلا: "اتفقت الأمة، بل سائر الملل؛ على أن الشريعة وضعت للمحافظة على الضروريات الخمس، وهي: الدين، والنفس، والنسل، والمال، والعقل. وعلمها عند الأمة كالضروريّ. ولم يثبت لنا ذلك بدليل معين، ولا شهد لنا أصل معين، يمتاز برجوعها إليه، بل علمت ملاءمتها للشريعة بمجموع أدلة لا تنحصر في باب واحد، ولو استندت إلى شيء معين لوجب عادة تعيينه. 
وأن يرجع أهل الإجماع إليه، وليس كذلك؛ لأن كل واحد منها بانفراده ظني، ولأنه - كما يتعين في التواتر المعنوي أو غيره أن يكون المفيد للعلم خبرا واحدا دون سائر الأخبار - كذلك لا يتعين هنا؛ لاستواء جميع الأدلة في إفادة الظن على فرض الانفراد، وهكذا سائر الأدلة في قواعد الشريعة وبهذا امتازت الأصول عن الفروع، إذْكانت الفروع مستندة إلى آحاد الأدلة، وإلى مآخذ معينة، فبقيت على أصلها من الاستناد إلى الظن بخلاف الأصول فإِها مأخوذة من استقراء مقتضيات الأدلة بإطلاقِ، لا من آحادها على الخصوص ". وعليه، فإنَّ كُلَّ مقصد من المقاصد الضرورية الخمسة لم يثبت بآحاد النصوص، وإنما ثبت بكثرة النصوص المتواترة الواردة فيه بمختلف صيغها ودلالاتما ومتعلقاتما. ومن تفحص الشريعة وجدها مليئة من أولها إلى

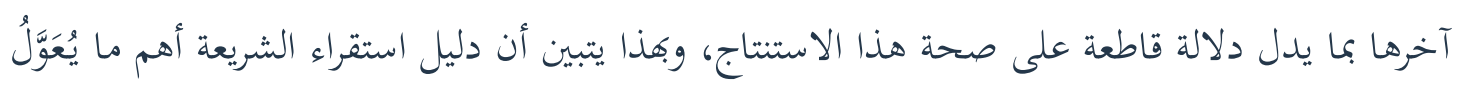
عليه في الاستدلال القطعيّ على المقاصد الشرعية العامة الكلية بأنواعها الثلاثة: الضروريّة، والحاجيّة، والتحسينيّة بإطلاقِ، وهو ما يؤكده دليل العقل.

2. - 2. - 2. - 2. دليل العقل:

إن الحديث عن دليل العقل يهيلنا على المسألة المعروفة في علمي: الكلام، وأصول الفقه، بمسألة التحسين والتقبيح العقليين، وهي من المسائل الخلافية الكبرى التي انقسم الرأي الإسلامي بشأها إلى أربعة آراء أساسية، وهي: رأي المعتزلة، ورأي الأشاعرة، ورأي الماتريدية، ورأي ابن تيمية، وهذه خلاصتها مع بيان وجه

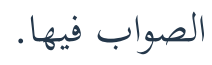
إن مسألة التحسين والتقبيح العقليين، تتلخص في الإجابة عن الأسئلة الآتية: هل الصفات القائمة بذوات الأشياء والأفعال صفات طبيعية موجودة فيها خلْقة، أم هي مكتسبة طارئة عليها بحكم الشرو؟ وهل بمقدور العقل إدراك ما في الأشياء والأفعال من أوصاف؛ والحكم عليها بالحسن أو القبح، أم أنه لا قدرة له على كلى ذلك إطلاقاً، وإن الأمر متوقف على حكم الشرع؟ وهل الإنسان مكلف في الدنيا وبجازى في الآخرة بمقتضى العقل، أم أنه لا تكليف عليه ولا جزاء له إلا بعد مجيء الشرع؟ فهذه التساؤلات هي المحاور الأساسيَّة للمسألة أعلاه، ولكلِّ وجهةٌ نظرٍ فيها. أما وجهة نظر المعتزلة فتقوم على نظرية التحسين والتقبيح العقليّين كما قال أئمة الاعتزال:" إن أصول المعرفة وشكر النعمة واجب قبل ورود السمع. والحسن والقبح يجب معرفتهما بالعقل، واعتناق الحسن واجتناب 
القبيح واجب كذلك، وورود التكاليف ألطاف الباري تعالى أرسلها إلى العباد بتوسط الأنبياء عليهم السلام..." وجملة هذه النظرية أن الأشياء والأفعال ذات أوصاف طبيعية موجودة فيها ابتداء، بتعلها حسنة أو قبيحة في نظر العقل قبل مجيء الشرع. وهو معنى القاعدة الاعتزالية: "العقل قبل ورود السمع ". ومنْ تَمَّم فالتكليف والجزاء من مقتضيات العقل ما دام قادرا على معرفة ما في الأشياء والأفعال من حُسْنٍ أو قُبْحِ، ومن صلاح أو فساد، ومن خير أو شر. وما بعثة الرسل ونزول الشرائع إلا من باب الألطاف الإلهية المؤّدة لمعارف العقل ومداركه لأصول الاعتقاد ومبادئ التشريع، فهذا عُحصّلُ نظرية الاعتزال في المسألة. وتتبنّى وجهة نظر الأشاعرة نظرية التحسين والتقبيح الشرعيين، كما قال مؤسسها الإمام أبو الحسن الأشعري:" والواجبات كلها سمعية، والعقل ليس يوجب شيئا، ولا يقتضي تحسينا ولا تقبيحا، فمعرفة الله

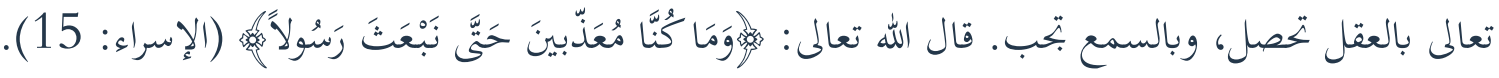
وجملة هذه النظرية: أن الأشياء والأفعال لا تحمل في ذاتما أوصافا حسنة ولا قبيحة، بل الحسَنُ منها ما

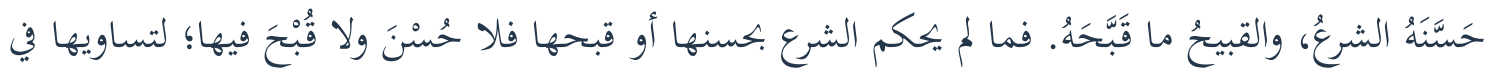
الحسن والقبح إلى أن يجيء الشرع فيحكمَ بما شاء على ما شاء منها بالحسن أو القبح فتصير -حينئذٍ حسنةً أو قبيحةً بهكم الشارع وأما العقل فلا قدرة له على إدراك ما في الأشياء والأفعال من حسن أو قبح، ولا حق له في الحكم بشيء من ذلك. أي ما في الأشياء والأفعال من مصالح أو مفاسد . وهو ما قرره الإمام الشاطبي قائلاً: "إن كون المصلحة مصلحة تقصد بالحكم، والمفسدة مفسدة كذلك، مما

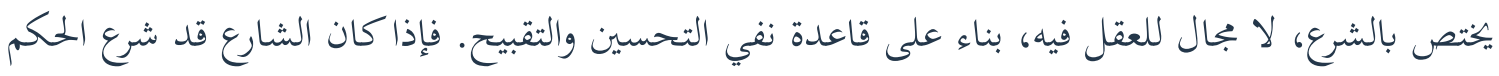
لمصلحة ما فهو الواضع لها مصلحة، وإلا فكان يمكن عقلا أن لا تكون كذلك، إذ الأشياء كلها بالنسبة إلى وضعها الأول متساوية لا قضاء للعقل فيها بحسن ولا قبح. فإذا كون المصلحة مصلحة هو من قبل الشارع، بحيث يصدقه العقل وتطمئن إليه النفس،" بمعنى أن المصالح ليست في ذاتما مصالح، ولا المفاسد في ذاتا مفاسد ابتداءً، بل يمكن أن ينعكس الأمر بينهما تماما بناء على قولمم بـ "مبدأ التجويز." فهذا بجمل وجهة نظر الأشاعرة في المسألة.

وحاصل وجهة نظر الماتريدية فحاصلها أن معرفة حقائق الأشياء والأفعال وما فيها من حسن أو قبح أو نفع أو ضرر، كل ذلك من مدارك النظر، إضافة إلى الحواس وبجيء الأخبار بها، كما قال الإمام أبو منصور 
الماتريدي:" سبيل العلم بحقائق الأشياء هي: العيان، والأخبار، والنظر ... وأن محاسن الأشياء ومساوئها، وما قَبُعَح من الأفعال وما حَسُسَ منها فإنما فاية العلم بها وقوع الحواس عليها وورود الأخبار ... والنظر فيها. وعلى ذلك أمر المكاسب الضارة والنافعة." وبناء عليه ف" قد ثبت حسن معرفة المنعم (الله) والشكر له في العقل وقبح الجحود له والكفران بنعمته." ولهذا، فلو لم يكن العقل قادراً على معرفة الله، وما تنطوي عليه الأفعال والأحكام من مصالح أو منافع لما استطاع أحد أن يصدق الرسل فيما جاءوا به؛ لأن " ما حسَّنته العقول وقَبَّحَتُهُ دعا إليه الرسل، كالصدق، والعدل بالنسبة للمحاسن، والجور، والكذب بالنسبة للقبائح". وكل ذلك من مُسَلَّمَات العقول ابتداءً و "حق القول في العقول، وهو القيام بشكر المنعم، ومعرفة حقيقة النعم، والنهي عن كفران المنعم، والجهل بحقيقة النعم. ولولا ذلك لم يحتمل أحد الأمر والنهي ابتداءً". ولذلك "فالعقل والنظر اللذان بمما تعرف المنافع والمضار أحق أن لا يهملا." وهذه الدعوة المتكررة من أبي منصور إلى الاحتفاء بالعقل، والإشادة بقدرته على اكتساب المعارف لا تعني استغناءه بذاته عن الرسل، ولا بإطلاقية معارفه واستقلاله فيها عن خالقه، وإنما هي من باب تقدير العقل والاعتراف بقيمته وقدرته المعرفية وعدم إلغائه بالمرة ليس إلا؛ لأن " العقل إذ هو سبب مخلوق؛ له حد كغيره من أسباب الإدراك، يعترضه ما يعترض غيره مع غموض الأشياء واستغلاقها" ومعلوم أن المخلوق، كيفما كان، فهو محدود القدرات، نسبيُّ المعارف. وما عَجْزُ العقول عن الإحاطة بجميع العلوم، واختلافها في إدراك المصالح وتقديرها، وتفاوها في الحكم على الأشياء والأفعال، واحتياج بعضها إلى بعض في طلب التعاون والمشورة... إلا دليل على انتهاء عاقبة العقول إلى مَنْ يُعينُهَا ويَرَدُهَا إلى ما جُعلَتْْ له من الصلاح والمعرفة. ومعلوم أنْ لا أحد أعلم بذلك من خلقها وأنشأها وفي ذلك لزوم القول.... بحاجة العقول للرسل، وعجز العقول عن الإحاطة بالكل. فالعقل عند الماتريدية، وإن كان قادراً على معرفة الحسن والقبح، فهو" عاجز بنفسه؛ لأنه آلة، والآلة لا تعمل بدون الفاعل، فلا يصلح أن يكون موجباً بنفسه شيئاً، ولا مُدركًاً بنفسه حسنَ الأشياء وقُبحها." ولذلك فهو غيرُ كافٍ في وجوب الاستدلال وحصول المعرفة إلا بانضمام دليل الشرع إليه، وتوفيق الله له من قبل ومن بعد؛ فكم من عاقل لما حرم الهداية والتوفيق لم يهتد إلى سواء الطريق، ولم يعرف سبيل الرشد بعقله فهلك. وكم من مسلم عرف سبيل الرشاد وسلك طريق السداد، ثم لما أدركه الحنذلان ضَلَّ عن الطريق بالارتداد... فثبت أنه لا كفاية بالعقل بحال، ولا معونة إلا من عند الكريم المتعال . 
ولهذا؛ حصر الماتريدية قدرة العقل في معرفة حسن شكر المنعم قبل مجيء الرسالة؛ لأنه لا عذر لأحد في الجهل بخالقه وهو يتأمل مظاهر الخلق، ويتعلم من التجارب. وأما باقي التكاليف الشرعية فليست من موجبات العقل، بل تتوقف على بجيء الشرع، فتقوم به الحجة على المكلفين متى جاء. فهذا جامع هذه النظرية. أما ابن تيمية فقد عرض وجهة نظره في مسألة التحسين والتقبيح العقليين في مواطن كثيرة من مصنفاته، وانتهى فيها إلى عدد من الخلاصات، حيث يرى ابن تيمية أن قضية التحسين والتقبيح العقليين من أعظم القضايا اليقينية، التي تفوق في يقينيتها القضايا الكلية العقلية، ودليله في ذلك أن كثيرا من الناس لا يعلمون عن الممستلَّمَات العقلية شيئاً، مثل: عدم اجتماع النقيضين، كالنفي والإثبات، والوجود والعدم، بينما كل العقلاء يعلمون بالفطرة والحس والعقل والتجربة حسن العدل والصدق والعلم، وقبح الظلم والكذب والجهل، ويميزون بينها ويحبون الأولى، ويثنون على أهلها، ويكرهون الثانية، ويذمون أصحاها؛ ولذلك فهي من أشهر المعلومات بين الأمم. ويرى أنه لا خلاف بين سلف الأمة وأئمتها في قضية التحسين والتقبيح العقليين، فلم

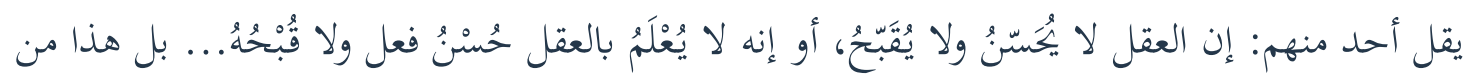
المحدثات في زمن أبي الحسن الأشعري .

كذلك يرى أنه لا تماثل بين أوصاف الأشياء، ولا تشابه بين أحكام الأفعال، وأن الأوصاف والأحكام ليست نسبية أو إضافية فقط، بل كل فعل أو حكم يتصف في نفسه بما يتصف به من حسن أو قبح، أو نفع أو ضرر، أو ملاءمة أو منافرة، ويتميز به من غيره، وكل من ينكر الحسن والقبح العقليين، ويعُلُّ جميع الشريعة من قسم الامتحان، ويقول: إن الأفعال ليست لها صفات حسنة ولا قبيحة قبل الشرع فقد أنكر الفطرة والعقل والشرع، وقوله ضعيف مخالف للكتاب والسنة ولإجماع السلف والفقهاء . أما صفات الأشياء وأحكام الأفعال فهي عند ابن تيمية صفات ذاتية ثابتة موجودة فيها ابتداء، وليست طارئة عليها بحكم الشرع، لكنها عند التحقيق ليست صفات لازمة، بل هي عارضة للأفعال بحسب ملاءمتها ومنافرتا لطبيعة الإنسان، فالحسن والقبح بمعنى كون الشيء محبوباً ومكروهاً، ونافعاً وضاراً، وملائماً ومنافراً، فهذه صفات ثبوتية لموصوفاتا، لكنها تتنوع بتنوع أحوالها وتتغير بحسب ما تقتضيه الحكمة الإلهية فيها من مصالح العباد. وفيما يتعلق بالمعرفة العقلية المتعلقة بالتحسين والتقبيح فهي معرفة إجمالية، وليس 
بمقدور العقل أن يجيط بكل شيء علماً، فالعلم بوجود الله، وما يتصف به من مطلق صفات الكمال، وما يشتمل عليه خلقه وشرعه من منتهى الحكمة والمصلحة، ومعرفة الغاية التي تكون عليها عاقبة الأفعال من السعادة والشقاوة في الدار الآخرة، كل ذلك لا يُعرَفُ على وجه الثفصيل إلا بالشرع . وأخيراً، فإنه لا تلازم بين التحسين والتقبيح العقليين، والتكليف والجزاء الإلهيين. فإذا كانت معرفة الحسن والقبح تتم جمملا بالعقل ابتداء، فالتكليف والجزاء لا يتم كل منهما إلا بالشرع مفصلا. وهذا محا غلط فيه غلاة القائلين بالتحسين والتقبيح، فإغمم قالوا: إن العباد يعاقبون على أفعالمم القبيحة ولو لم يبعث الله إليهم

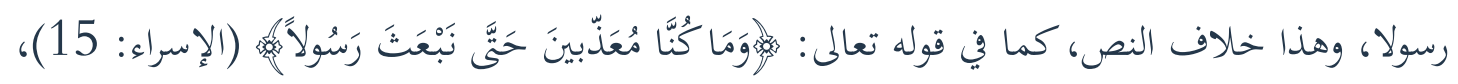

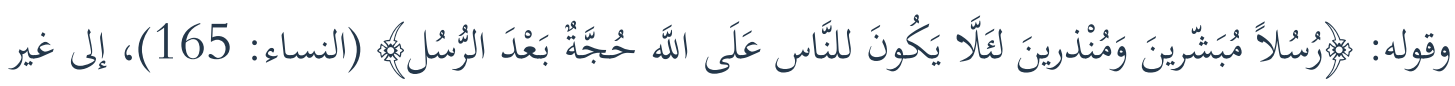
ذلك من النصوص الدالة على أن العقوبة قبل الحجة ليست مشروعة، وأن الله لا يعذب إلا بعد الرسالة، ومن لم تبلغه جملة لا يُعَنَّبُ أصلاً، ومن بلغته جملة دون بعض التفصيل لا يعذب إلا على إنكار ما قامت عليه الحجة الرسالية. فهذا محصل رأي شيخ الإسلام في المسألة .

مما سبق نجد أن أنظار جميع المدارس الإسلامية قد تقاطعت في مسألة التحسين والتقبيح العقليين في مجالات، وتفردت هذه المدارس في مجالات أخرى، فقد تقاطع الجميع في القول بنسبية المعارف العقلية؛ فليس في علماء المسلمين -من مختلف المدارس- من قال بإطلاقية حكم العقل قبل بجيء الشرع فضلا عما بعد مجيئه، إذْ لا حاكم بإطلاق إلا الله وتقاطع المعتزلة والماتريدية وابن تيمية في القول بمبدأ التحسين والتقبيح العقليين، وثبوت أوصاف الأشياء والأفعال والتروك، واختلافها في الأحكام، ونفي مبدأ التجويز . وتقاطع الأشاعرة والماتريدية وابن تيمية في القول بمبدأ توقف التكليف والجزاء على مجيء الشرع انفرد المعتزلة بمبدأ التلازم بين التحسين والتقبيح، والتكليف والجزاء قبل إقامة الحجة على المكلفين بالرسالة، وانفرد الأشاعرة بنفي التحسين والتقبيح العقليين، وإنكار اختلاف أوصاف الأشياء والأفعال، واعتماد مبدأ التجويز. كما انفرد الماتريدية بوجوب شكر المنعم بالعقل قبل ورود الشرع، وتوقف باقي التكاليف على نزوله، وانفرد ابن تيمية بالقول بتغير أوصاف الأشياء والأفعال بتغير الأحوال، وما تقتضيه الحكمة الإلهية من رعاية المصالح. وبالجملة، فعلى الرغم من كل هذه التجاذبات حول مسألة التحسين والتقبيح العقليين؛ فقد آل النظر فيها إلى الاتفاق بين مختلف المدارس الإسلامية، كما قال ابن القيم: "فقد رغب عن القول بنفي التحسين 
والثقبيح العقليين فحول الفقهاء والنَُّّار من الطوائف كلهم، فأطبق أصحاب أبي حنيفة على خلافه، وحكوه عنه نصَّاً، واختاره من أصحاب أحمد: أبو الخطاب، وابن عقيل، وأبو يعلى الصغير. ولم يقل أحد من متقدميهم بخلافه، ولا يمكن أن ينقل عنهم حرف واحد موافق للنفاة. واختاره من أئمة الشافعية الإمام القفال الكبير، وبالغ في إثباته، وبنى كتابه "محاسن الشريعة" عليه، وأحسن فيه ما شاء. وكذلك الإمام سعيد بن علي الزنجاني، بالغ في إنكاره على أبي الحسن الأشعري القول بنفي التحسين والتقبيح، وأنه لم يسبقه إليه أحد. وكذلك أبو القاسم الراغب، وكذلك أبو عبد الله الحليمي، وخلائق لا يكصون، وكل من تكلم في علل الشرع ومحاسنه وما تضمنه من المصالح ودرء المفاسد." بل إن من كبار نفاة التحسين والتقبيح من اضطروا اضطراراً إلى التراجع والاعتراف بمصداقية نظرية التحسين والتقبيح العقليين، لكن بنوع من "التقية" والاحتياط في التعبير عنها، أمثال: الإمام الجويني، والغزالي، والشاطبي أما الإمام الجويني فقال: "ولسنا ننكر أن العقول تقتضي من أرباجها اجتناب المهالك، وابتدار المنافع الممكنة، على تفصيل فيها وجحد هذا خروج عن المعقول." فهذا النص أشبه بنظرية التحسين والتقبيح العقليين، وهو اعتراف واضح بوجود المهالك والمنافع التي تدركها العقول، وتفرق بينها، وتقتضي اجتناب الأولى وابتدار الثانية؛ لأن جحود مقتضيات العقول

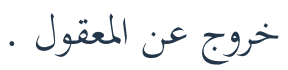
وأما الإمام الغزالي فلم يمنعه من القول بالتحسين والتقبيح العقليين إلا حاجز الخوف من "الانتساب إلى الاعتزال "كما قال في حديثه عن مراتب المقاصد: "فأعلاها ما يقع في مراتب الضرورات، كحفظ النفس فإنه مقصود الشارع... والعقول مشيرة إليه وقاضية به لولا ورود الشرائع... ولا ننكر إشارة العقول إلى جهة المصالح والمفاسد، وتحذيرها المهالك، وترغيبها في جلب المنافع والمقاصد.... وإنما نبهنا على هذا القدر؛ كي لا نُنْسَبَ إلى اعتقاد الاعتزال، ولا يَنْفرُ طبع المسترشد عن هذا الكلام خيفَةَ التضمخخ بعقيدة مهجورة، يرسخ في نفوس أهل السنة قجينها.!! فليعتقد على هذا التأويل، أن العقول ترشد إلى الزجر عن القتل بالقصاص." وقال في سياق تعليله لتحريم الخمر: "...فهذا -أيضا -مما لا يجوز أن تنفك عنه عقول العقلاء..." فهذه نصوص واضحة الإقرار بإشارة العقول إلى جهة المصالح والمفاسد، وتحذيرها المهالك، وترغيبها في جلب المنافع والمقاصد، وقضائها بجفظ النفوس، وإرشادها إلى الزجر عن القتل بالقصاص حتى ولو لم ترد به الشرائع، وقدرتا على تعليل تحريم شرب الخمر بكونه مفسدا للعقل؛ لأنه مما لا يجوز أن تنفك عنه عقول 
العقلاء. وهذا هو جوهر نظرية التحسين والتقبيح العقليين، إلا أن أبا حامد أبى الإعلان عنها صراحة، ولا عذر له غير قوله: "كيلا يَظَُُّّ بنا ظان استمدادنا في هذه التصرفات من معتقدات أرباب الضلال، وطبقات

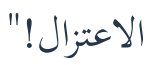

وأما الإمام الشاطبي فقد اعترف في أكثر من نص بقدرة العقل على إدراك المصالح والمفاسد والتمييز بين المحاسن والقبائح في فترات انعدام الشرائع. فقال: "إن من تقدم ممن لا شريعة له يتبعها، أو كان له شريعة درست، كانوا يقتضون المصالح الدنيوية بكف كل من اتبع هواه في النظر العقلي، وما اتفقوا عليه إلا لصحته عندهم، واطراد العوائد باقتضائه ما أرادوا من إقامة صلاح الدنيا... فهذا أمر توارد النقل والعقل على صحته على الجملة، وهو أظهر من أن يستدل عليه." وقال في سياق آخر: "إن الالتفات إلى المعاني قد كان معلوما في الفترات، واعتمد عليه العقلاء حتى جرت بذلك مصالحهم... وأن المشروعات في هذا الباب جاءت متممة لجريان التفاصيل في العادات على أصولها المعهودة، ومن هاهنا أقرت هذه الشريعة جملة من الأحكام التي جرت في الجاهلية... وما كان من محاسن العوائد ومكارم الأخلاق التي تقبلها العقول وهي كثيرة." وقال -أيضاً-- "إن المشروعات المكية... كانت في غالب الأحوال... جارية على ما تقتضيه العادات عند أرباب العقول، وعلى ما تحكمه قضايا مكارم الأخلاق من التلبس من كل ما هو معروف في محاسن العادات والتباعد عن كل ما هو منكر في محاسن العادات... فكان أكثر ذلك موكولا إلى أنظار المكلفين... على حسب ما تستحسنه العقول السليمة في ذلك الترتيب..."

فهذه كلها نصوص واضحة الدلالة على مدى قدرة العقل وإدراكه للمصالح والمفاسد، والتمييز بينها قبل مجيء الشرع، وقد سقتها كلها لأبرهن على أن الرأي العام الإسلامي مع قدرة العقل على إدراك المصالح والمفاسد، ومعرفة ما في الأشياء والأفعال من حسن أو قبح على وجه الإجمال والتقريب والتغليب، لا على كلى وجه التفصيل والإطلاق والاستقلال الكليّ والاستغناء التام عن شرع الله؛ لأن " العقول لا تستقل بإدراك مصالحها دون الوحي." ولأن المعرفة المطلقة تتوقف على العلم المطلق بماهية الأشياء ابتداء. " وماهية الأشياء لا يعرفها على حقيقتها إلا باريها. فتسور الإنسان على معرفتها رمي في عماية. " والسبب في نسبية المدارك العقلية هو " أن الله جعل للعقول في إدراكها حدا تنتهي إليه، لا تتعداه، ولم يجعل لها سبيلا إلى الإدراك في كل مطلوب، ولو كانت كذلك لاستوت مع الباري في إدراك جميع ما كان، وما يكون، وما لا يكون لو كان 
كيف كان يكون، فمعلومات الله لا تتناهى، ومعلومات العبد متناهية، والمتناهي لا يساوي ما لا يتناهى. والحاصل من هذه القضية أنه ينبغي للعقل أن لا يتقدم بين يدي الشرع، فإنه من التقدم بين يدي الله ورسوله، بل يكون ملبيّا من وَرَاء وَرَاءٍ." وهذا القَدْرُ كافٍ للدلالة على مقصودنا من دليل العقل بما هو أداة معرفية منضبطة بمقاصد الشرع وحدود العقل نفسه، لا بما هو أداة معرفية متفلتة من كل ضابط عقلي أو مقصد شرعي لم تستفد منه البشرية غير تدمير مصالحها، كما يشهد بذلك زمان مرجعية العقل المجرد عن تسديد الوحي. وعليه، إذا كان العقل قادرا على إدراك المصالح والمفاسد عموماً فأولى المصالح بالإدراك هي المصالح الضرورية الحمس؛ لشهرتا، وظهورها، وحاجة الناس إليها؛ إذ بدوغا لا وجود للإنسان، فهي علة وجود الحياة البشرية وضمان استمرارها ومايتها والمحافظة عليها من الفساد، وإلا آل العمران البشري إلى الفوضى فالخراب، وهو ما يشهد له دليل الواقع كذلك.

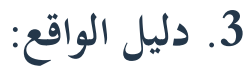

وأما دليل الواقع فهو ما علم بالتجارب وبجاري العادات، أي: ما شهد له الوجود الحسي، وأفضت إليه المشاهدة ورصد واقع الحياة، فتبين أنه من الكليات الوجودية المتميزة بالثبات والظهور والانضباط والعموم وعدم التغير بتغير الزمان والمكان والأشخاص والأحوال، وكل ما يرتبط بالواقع العام، وهو ما جاءت الشريعة موافقة له، منسجمة معه، كما قال الإمام الشاطبي:" إن مجاري العادات في الوجود أمر معلوم لا مظنون، وأعني: في الكليات، لا في الجزئيات، والدليل على ذلك أنّ الشرائع بالاستقراء إنما جيء بها على ذلك. ولنعتبر بشريعتنا، فإن التكاليف الكلية فيها بالنسبة إلى من يكلف من الخلق موضوعة على وزان واحد، وعلى مقدار واحد، وعلى ترتيب واحد، لا اختلاف فيه، بحسب متقدم ولا متأخر، وذلك واضح في الدلالة على أن موضوعات التكليف -وهي أفعال المكلفين- كذلك. وأفعال المكلفين إنما تجري على ترتيبها إذاكان الوجود باقيا على ترتيبه، ولو اختلفت العوائد في الموجودات لاقتضى ذلك اختلاف التشريع، واختلاف الترتيب، واختلاف الخطاب، فلا تكون الشريعة على ما هي عليه، وذلك باطل." والمقاصد الضرورية هذا شأها، فهي باقية منذ وجودها على ما هي عليه من الكلية والثبات والاطراد والعموم والدوام، وهذا بَينّ، إذْ قد عُلمَ أن مصالح الدنيا تدرك بالضرورات والتجارب والعادات والظنون المعتبرات، 
كما قال الإمام العز. وأعظم المصالح التي شهدت لها التجارب والعادات، ودل عليها منطق الفطرة والنظر في واقع الحياة، هي: المصالح الضرورية الخمس المعتبرة، كما قال الإمام الآمدي: "والحصر في هذه الخمسة الأنواع إنما كان نظرا إلى الوقوع والعلم بانتفاء مقصد ضروري خارج عنها في العادة." وهكذا، فإنّ حصر المقاصد الضرورية في خمسة لم يأت عبثاً ولا وُضعَ اعتباطاً أو لمجرد الاتفاق والمصادفة، بل جاء نتيجة عملية بحث دقيق، ونظر متفحص في واقع الحياة، واستقراء واسع لمفردات الشريعة، كما قال الإمام ابن أمير الحاج: "حصر المقاصد الضرورية في هذه الخمسة ثابت بالنظر للواقع وعادات الملل والشرائع بالاستقراء." وعليه، إذا ثبت أن الشرع إنما جاء بأمور معتادة جارية على أمور معتادة، كما تقدم بيانه. فذلك ما جعل "مقاصده تحظى بخاصيات الثبات والاطراد والعموم والإطلاق والاستمرار؛ لأن الشرع موضوع على أنه دائم أبدي لو فرض بقاء الدنيا من غير هاية،" شأنه في ذلك شأن القوانين الكونية الثابتة المطردة العامة المطلقة الباقية منذ خلق الله السماوات والأرض وما بينهما، وما فيهما من المنافع؛ لأن سنة الله في الخلق والشرع واحدة لا تتخلف ولا تختلف. فكما أن هناك سنناً كونية ثابتة، فهناك سنٌُ شرعية اجتماعية مستقرة كذلك، وهو ما يعبر بشكل واضح عن وحدة الإرادة الإلهية على مستوى الخلق والتشريع، ويحقق التوافق والانسجام والتناغم بين النواميس الكونية والقوانين الشرعية، وينأى بهما عن التناقض والتصادم والعبث. ولهِفرَّرَتَ اللَّه

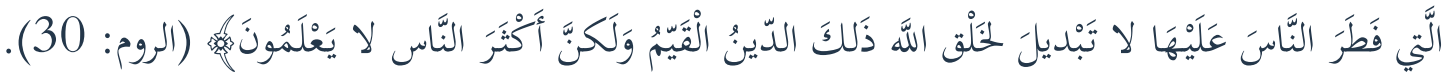
وهذا ما سعى إليه الإمام الشاطبي، إذْ "كانت غايته الوصول إلى كليات مقتبسة من الشريعة، تضاهي الكليات المقتبسة من الوجود، وتستوي معها في العموم والاطراد والثبوت من غير زوال، والحكومة على ما سواها من قول أو فعل." وهو ما نص عليه بجلاء في المقدمة التاسعة من "الموافقات." وإذذْ تبينت أدلة المقاصد الضرورية فإلى النظر في معاييرها.

\section{ثانياً: معايير المقاصد الضرورية.}

إذا كان الحكم على الشيء فرع عن معرفته فلابد من معرفة المعايير العلمية التي على أساسها نستطيع أن نقول: إن هذه المقاصد الشرعية ضرورية، وتلك غير ضرورية، فما هي هذه المعايير؟ إذا استقرأنا الفكر المقاصدي وجدنا أن المقاصد الشرعية الضرورية هي التي اجتمعت فيها الأوصاف الآتية، 
وهي أن تكون: ضرورية، وكلية، وقطعية، ومطلقة، وعامة، ودائمة، وثابتة، وظاهرة، ومنضبطة، ومُطَّرَة. ومتى فُقَدَتْ هذه القيود العشرة أو بعضها لمُ تعتبر من المقاصد الضرورية. والمراد بالضرورية: أها لابد منها، بحيث تتوقف عليها كلُّ مصالح الدنيا والآخرة وجوداً وعدماً، وهي: الدين، والنفس، والعقل، والنسل، والمال. وبالكلية: أن تعم فائدقا جميع الناس، لا بعضهم دون بعض، أو في حالة مخصوصة دون حالة. وبالقطعية: أن تكون مقصودة للشرع لا بدليل واحد، بل بأدلة خارجة عن الحصر . وبالإطلاق: أفا غير مقيدة بزمان ولا بمكان ولا بأشخاص ولا بظروف وأحوال معينة. وبالعموم: أغها عامة في جميع المكلفين، وليست خاصة ببعضهم دون بعض. وبالدوام: أهما مستمرة باقية لا تزول لو قُدِّرَ بقاء العالم إلى ما لا غاية. وبالثبات: أها لا

تتغير في حقيقتها، ولا تتبدل في جوهرها منذ وجودها إلى غايتها. وبالظهور: أفا واضحة بينة، بحيث لا يختلف العقلاء في تشخيصها. وبالانضباط: أها لا تزيد ولا تنقص عن عدد معين مضبوط. وبالاطراد: أهما لا تختلف باختلاف الأزمان والأماكن والأشخاص والظروف والأحوال. وبالجملة، متى اجتمعت هذه المعايير العشرة في مقصد ما حصل اليقين بأنه مقصد ضروريّ لا بد منه لقيام مصالح الدنيا والآخرة، بحيث لو فُقََّ

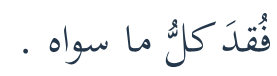
وهذه المعايير الموضوعية لا سبيل إلى تحديدها إلا بطول التأمل، وتعميق النظر، واستفراغ الوسع في الاستقراء لموارد الشريعة ومصادرها، وبجاري العادات والتجارب، ومذاكرة أهل العلم، والاستئناس باجتهادات الأئمة المبرزين في الموضوع، كما قال الإمام ابن عاشور: "على الباحث في مقاصد الشريعة أن يطيل التأمل، ويجيد التثبت في إثبات مقصد شرعي، وإياه والتساهل والتسرع في ذلك؛ لأن تعيين مقصد شرعي - كلي أو جزئي- أمر تتفرع عنه أدلة وأحكام كثيرة في الاستنباط، ففي الخطأ فيه خطر عظيم. فعليه أن لا يعين مقصداً شرعياً إلا بعد استقراء تصرفات الشريعة في النوع الذي يريد انتزاع المقصد التشريعي منه، وبعد اقتفاء آثار أئمة الفقه ليستضيء بأفهامهم، وما حصل لهم من ممارسة قواعد الشرع. فإن هو فعل ذلك اكتسب قوة استنباط يفهم بها مقصود الشرع." وحاصل القول: كل ما كان من المقاصد الشرعية بحيث لا يمكن الاستغناء عنه بحكم حتميته النابعة من أوصافه الذاتية، وثبوته العلمي اليقيني الراجع إلى أدلثه القطعية من الاستقراءات الشرعية المتواترة، والمدارك العقلية الراجحة، والعادات الواقعية المألوفة، فهو من المقاصد الضرورية، وكل ما لم يكن كذلك من حيث أوصافه وأدلته، فهو من المقاصد الحاجية أو التحسينية. وإذا تبينت معايير المقاصد 
الضرورية، فلنجمل القول في الإضافات المقاصدية القديمة.

ثالثاً: مجمل الإضافات المقاصدية القديمة.

إذا نظرنا في الإضافات المقاصدية القديمة على المقاصد الضرورية الخمسة المعلومة، وجدناها لا تخرج عما

يأني:

فهناك مَنْ أضافَ " العُضَْ أو الأعراضَ " إلى مُسَمَّى المقاصد الضرورية فصارت ستةً، كالقرافي، (ت684 هـ)، وابن السبكي، (ت 771هـ)، والشوكاني، (ت 1250هـ). وهناك مَنْ عَبَّرَ بـ "النَّسَب أو الأنساب " وبـ" العزضض أو الأعراض "عن " النَّسنل"، كالرازي، (ت606هـ)، والبيضاوي، (ت685هـ)، والإسنويّ، (ت 772هـ). وهناك من حددها في خمسة، لكنه عبر بـ "الأنساب" عن "النسل" مع إثبات "الأعراض" و إسقاط "الأديان"، كالقرافي، والآبي، (ت827هـ). وهذا وسابقه فيهما من عدم الحصر والضبط ما فيهما، ولو على مستوى اللفظ. وهناك من انتقد " مبدأ الحصر " من أصله وأضاف " العبادات الظاهرة والباطنة وحقوق العباد بعضهم على بعض " وغيرها من مشمولات المصالح الشرعية، فأصبحت غير محصورة في عدد معين كابن تيمية. (ت728هـ). وهناك من قسم المصالح الشرعية إلى خمسة أقسام، وجعل حفظ المصالح الضرورية الخمس قسماً واحداً منها فقط، كابن فرحون، (ت 799ه). وفيما يأتي مراجعة هذه الإضافات المقاصدية. 1 1 1 إضافة العرض والنسب

أهم ما أضافه علماؤنا القدامى إلى المقاصد الضرورية الخمسة: العزضض، والنَّسَب، وغيرهما مما تفرد به ابن تيمية (ت 728هـ)، وابن فرحون (ت 799هـ). فأما "العزرضُ" فهو من المقاصد الشرعية التي استأثرت باهتمام كثير من الأصوليين القدماء، فمنهم من لم يذكر "الأديان" وذكر "الأعراض"، كما قال الإمام القرافي:

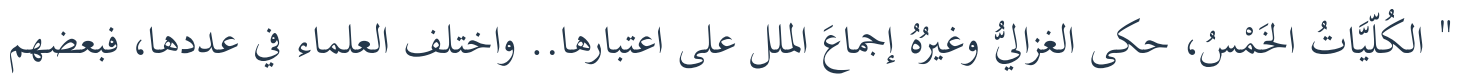
يقول الأديان عوض الأعراض، وبعضهم يذكر الأعراضَ ولا يذكر الأديان." ومنهمم مَنْ عَدَّ العُضَ مقصداً ضرورياً سادساً حسبما حققه الإمام القرافي -أيضاً - إذْ قال: "وفي التحقيق الكلهُ متفق على تحيمه، فما أباح الله تعالى العُض... وكذلك لم يبح الأموال ولا الأنساب.. ولا العقول.. ولا النفوس.. ولا الأديان." وهو ما ذهب إليه الإمام ابن السبكي فقال: " والمناسب ضروريّ فحاجيّ فتحسينيّ. والضروريّ: كحفظ الدين 
فالنفس فالعقل فالنسب فالمال والعرض." ومنهم من دافع بقوة عن العرض وعَلَّهُ أولى بمسمى الضروريّ، فقال: "الضروريّ: وهو المتضمن لحفظ مقصود من المقاصد الخمسة التي لم تختلف فيها الشرائع، بل هي مطبقة على حفظها، وهي خمسة: أحدها: حفظ النفس.. ثانيها: حفظ المال.. ثالثها: حفظ النسل.. رابعها: حفظ الدين.. خامسها: حفظ العقل..، وقد زاد بعض المتأخرين سادساً، وهو حفظ الأعراض، فإن عادة العقلاء بذل نفوسهم وأمواهم دون أعراضهم، وما فدي بالضروريّ فهو بالضروريّ أولى، وقد شرع في الجناية عليه بالقذف الحد، وهو أحق بالحفظ من غيره، فإن الإنسان قد يتجاوز عمن جنى على نفسه أو ماله، ولا يكاد أحد يتجاوز عمن جنى على عرضه. ولذذا يقول قائلهم:

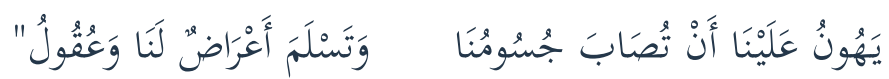
وهذا الذي قرره هؤلاء الأعلام بشأن "الأعراض" لا اعتراض عليه من حيث دلالته على أهيتها ووجوب مايتها بما هو أنفس وأغلى منها، لكن الاعتراض على عدها من المقاصد الضرورية التي متى انعدمت انعدمت جميع متعلقاتا، كما بيناه في ماهيتها ومعاييرها. ولذلك نقول: لو عمت البلوى بالقذف والسباب والشتيمة في "الأعراض" بين الناس، هل ستفضي هذه البلوى العامة بالبشر جميعا إلى هايتهم العامة، أو أها لن تزيد على شيوع الخصومة والعداوة والبغضاء والمشاجرة وتفريق ذات البين، وما إلى ذلك من المشاكل العائلية والاجتماعية التي يعيش الناس معها في ضيق وحرج ومشقة وعسر حياة ليس إلا؟ لا شك أن أقصى ما تفضي إليه هذه البلوى هو سُوء العلاقات الاجتماعية وتفككها؛ ولذلك كان حفظ "العرض" مما تحفظ به كرامة الإنسان عن الإهانة، ويصان به شرفه عن الامتهان. وتحمى به مواقع المدح والذم منه عن سيئ الأقوال والشائعات، وكل ذلك مما ييسر التواصل ويسهل الاندماج بين فئات المجتمع، ويساعد على تمتين الروابط العائلية، ويضيق من منافذ الفرقة، ويقلل من أسباب تفسيخ النسيج الاجتماعي العام. ويشيع المحبة والألفة والائتلاف، وما إلى ذلك من المصالح العامة الرافعة للحرج والعنت والعسر والمشقة عن العلاقات العامة وهذه المعاني هي المستفادة من كلمة "عرض" في لسان العرب، إذ مدار دلالتها اللغوية على الحسب والنفس والبدن والجسد وموضع المدح والذم من الإنسان. وقد حققه ابن الأثير في النهاية فقال:" العرضُ موضع المدحح والذم من الإنسان سواء في نفسه أو في سلفه أو مَنْ يلزمه أمره."

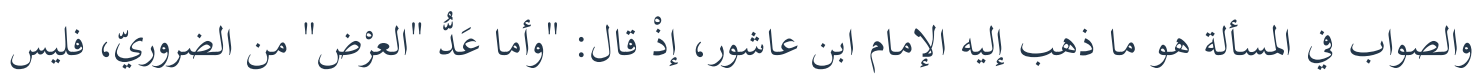


بصحيح... والصواب أنه من قبيل الحاجيّ." وهذا ما انتهى إليه الأستاذ الريسوني في تعقيبه على ما سبق من كلام الشوكاني عن حفظ "الأعراض" إذْ قال: "والحقيقة أن جعلَ "العرُض" ضرورةً سادسةً توضع إلى جانب ضرورات: الدين، والنفس، والنسل، والعقل، والمال، إنما هو نزول بمفهوم الضرورات، وبمستوى ضرورتها للحياة

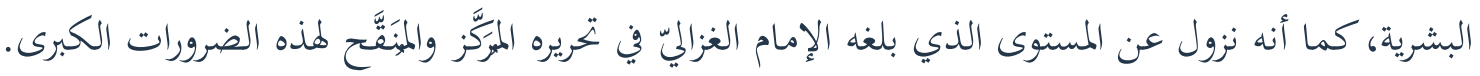
فبينما جعل الضروريّ هو حفظ النسل نزل بعض المتأخرين إلى التعبير بالنسب، ثم إلى إضافة العرض! وهل حفظُ الأنساب وصونُ الأعراض إلا خادمٌ لحفظ النسل؟ ثم إن حفظ العرض ينقصه الضبط والتحديد، فأين يبدأ؟ وأين ينتهي؟ وما هو الحد الفاصل بين حفظ العرض وحفظ النسب؟ ولو جاز لنا أن نضيف ضرورة النسب وضرورة العرض لجاز لنا أن نضيف -من باب أولى- ضرورة الإيمان، وضرورة العبادة، وضرورة الكسب، وضرورة الأكل، إلى غير ذلك من الضرورات الحقيقية المندرجة في الضرورات الخمس والخادمة لها والحق أن ما كان هذا شأنه فهو مكمل للضروري، كما أشرت من قبل." وفي تر هذا القدر من كلام الشيخ ابن عاشور، والأستاذ الريسوني ما يقطع بقيمة العرضض وأهميته، لكنه لا يرقى به إلى مرتبة المقاصد الضرورية، وإنما يبقى في حدود مرتبة المقاصد الحاجية الخادمة للمقاصد الضرورية، كما هو

وأما حفظُ "النَّسَب" فهو - كذلك- مما يجب الاعتناء به والمحافظة التامة عليه من الاختلاط والرِّيَب، كما قال إمام الزيتونة:" فَحرَصُ الشريعة على حفظ " النَّسَب " وتحقيقه ورفع الشك عنه ناظر إلى معنى نفساني عظيم من أسرار التكوين الإلهي، علاوة على ما في ظاهره من إقرار نظام العائلة، ودرء أسباب الخصومات الناشئة عن الغيرة المجبولة عليها النفوس، وعن تطرق الشك من الأصول في انتساب النسل إليها، والعكس." وكل هذا لا خلاف فيه، ومع ذلك فلا يمكن اعتبار حفظ "النسب" من المقاصد الضرورية، إذْ على فرض

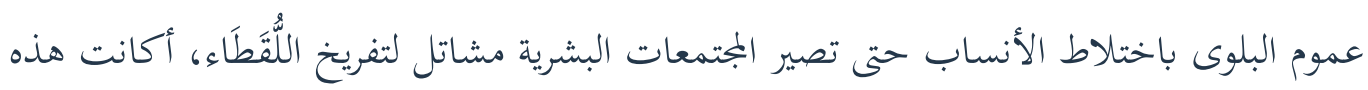
المجتمعات تحلك عن آخرها بسبب ذلك؟ فكم من لقيط بجهول نسب أحد الأبوين أو كَليهما، حيُّ يُرْزَقُ، لا يبالي من أين جاء. وإن ألزّ به ما أَمَّمنَ الحزن والحسرة والمعاناة النفسية والاجتماعية، والإحساس بالنقص في مجتمع محافظ، فلا يبلغ به كل ذلك مبلغ فقدان الحياة. بل إن مجتمعات بكاملها أصبحت لا تعير أنسابها أي اهتمام وإن أصاهما من ذلك ما أصاهما من أزمات ومشاكل اجتماعية، فإنها لم تبلغ بها مبلغ الهلاك التام، 


$$
\text { كما هو واقع الحال في كثير من المجتمعات الغربية. }
$$

ولذلك عَدَّ المحققون حفظ "النسب" من المقاصد الحاجية المساعدة على انتظام مؤسسة الأسرة، وتوثيق الروابط العائلية، وإشاعة التكافل الاجتماعي بين أفراد العائلة، ودفع الإحساس بالدونية والمعاناة النفسية وسوء العلاقات الفردية والجماعية، وما إلى ذلك مما يندرج في مسمى المصالح الحاجية العائدة على النسل بكزيد من الحفظ والتزكية والتيسير كما قال الإمام ابن عاشور: "إنْ أُريدَ بحفظ "النسب" انتساب النسل إلى أصله. فقد يقال: إنَّ عَلَّهُه من الضروريّ غيرُ واضح؛؛ إذْ ليس بالأمة من ضرورة إلى معرفة أن زيداً هو ابنُ عمروٍ وإنما ضرورةا في وجود أفراد النوع وانتظام أمرهم... فيكون حفظ "النسب" بهذا المعنى بالنظر إلى تفكيك جوانبه من قبيل الحاجيّ." وفي هذا القَدْر كفايةُ دلالةٍ على قيمة "النَّسَب" وترتيبه في قائمة المقاصد الحاجيَّة دون قائمة المقاصد الضروريّة لمن تأمله.

\section{2 إضافات ابن تيمية:}

وأما ما أضافه ابن تيمية من حفظٍ "للعبادات الباطنة والظاهرة "، فمن أعظم مقاصد الشريعة وقواعدها التي لا صلاح للبشرية إلا بها، غير أن ما سجله بشأها من استدراكات على بعض الأصوليين لا يخرج في فاية الأمر عن المقاصد الضرورية الحمسة، وما يحوم حولها من المقاصد الحاجية أو التحسينية فأما " مقاصد العبادات الظاهرة والباطنة من أنواع المعارف بالله تعالى وملائكته وكتبه ورسله، وأحوال القلوب وأعمالها، كمحبة الله وخشيته وإخلاص الدين له والتوكل عليه والرجاء لرحته ودعائه، وغير ذلك مما هو في هذا المعنى من مصالح الدنيا والآخرة." فهي من المقاصد الشرعية الراجعة إلى حفظ الدين بما هو إسلام وإيمان وإحسان في محلته النهائية، كما قال الإمام الشاطبي: " فإن حفظ الدين حاصله في ثلاثة معان، هي: الإسلام، والإيمان، والإحسان." وأما "ما شرعه الشارع من: الوفاء بالعهود، وصلة الأرحام، وحقوق الجيران، وحقوق بعضهم على بعض" فهي من المقاصد الحاجية. وأما "غير ذلك من أنواع ما أمر به وغى عنه؛ حفظا للأحوال السنية وتذذيب الأخلاق، وما في هذا المعنى محا جاءت به الشريعة من المصالح" فهي من المقاصد التحسينيّة. وهذا ما انتهى إليه الأستاذ يوسف أحمد البدوي في رسالته عن "مقاصد الشريعة عند ابن تيمية" -أيضاً - إذْ قال: "وأن ما ذكره من المقاصد من أنواع المعارف بالله تعالى ودعائه، إنما هو راجع إلى حفظ الدين الباطن 
والظاهر، فيما يتعلق بالله سبحانه، وفيما يتعلق بالعبد ثم إن ما ذكره من مقاصد الوفاء بالعهود... وحقوق المسلمين بعضهم على بعض فإن هذا كذلك راجع إلى حفظ الدين وحفظ الضروريات الخمس الباقية، فهذه المقاصد إنما هي وسائل مكملة للضروريات الخمس شأها شأن باقي الأخلاق، وعلى هذا فلا خلاف بين ابن تيمية وغيره من الأصوليين في حصر المقاصد في الضروريات الخمس ". وهناك استدراك آخر لشيخ الإسلام على "مبدأ الحصر الخماسي" للمصالح الضرورية، يقول فيه: "...ودفع المضار بحفظ النفوس والأموال والأعراض والعقول والأديان التي حصر فيها بعض الناس المصالح، ومن قصر المصالح على العقوبات التي فيها دفع الفساد عن تلك الأحوال ليحفظ الجسم فقط، فقد قصر." وهذا الاستدراك بجانب للصواب من وجهين :

أحدهما: أن حفظ المقاصد الضرورية الخمسة؛ لا يقتصر على حفظ الجسم فقط. بل هي أساس كل مصالح الدنيا والآخرة، كما وضح بما لا مزيد عليه في ماهيتها.

وثانيهما: أن حفظ المقاصد لا يقتصر على شرع العقوبات فقط، بل إن المقاصد كما تحفظ بشرع العقوبات من جهة دفع المضار عنها، تحفظ -أيضاً- بضمان ما يقيمها ويديمها من جهة جلب المصالح إليها . وقد فَصَّلَ الإمام الشاطبيُّ فيما تحفظ به المقاصد الضرورية من الجهتين في أماكن متعددة من الموافقات، منها قوله: "فأما الضرورية فالحفظ لها يكون بأمرين: أحدها: ما يقيم أركاها ويثبت قواعدها، وذلك عبارة عن مراعاها من جانب الوجود. والثاني: ما يدرأ عنها الاختلال الواقع أو المتوقع فيها، وذلك عبارة عن مراعاها من جانب العدم. وقوله: "إن الأصول الكلية التي جاءت الشريعة بحفظها خمسة، وهي: حفظ الدين، والنفس، والعقل، والنسل، والمال. ولم ترذْ هذه الأمور في الحفظ من جانب العدم إلا وحفظها من جانب الوجود حاصل.... وتفصيله مذكور في مظانه من "الموافقات." و "مقاصد الشريعة" لابن عاشور. وبهذا يظهر

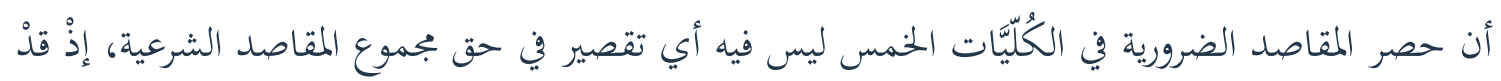
عُلمَ من الشريعة أن أعظم المقاصد جريان الأمور الضرورية الخمسة المعتبرة في كل ملة، وأن أعظم المفاسد ما لمان يكر بالإخلال عليها، والاستقراء يُبَينُ ذلك. 3. 3 إضافات ابن فرحون: أهم ما أضافه هذا العالم في مجال المقاصد هو تَوَسُعُعُهُ شيئاً ما في تقسيمها، حيث غدت أكثر تحديداً 
ووضوحاً، لكنه لم يأت بما يمكن اعتباره إضافة نوعية على المقاصد الضرورية الخمسة، بل كل ما جاء به لم يخرج عن حفظ هذه الضروريات فقال -رحمه الله-: "اعلم أن الله -سبحانه وتعالى - شرع الأحكام لحكمٍ منها ما أدركناه، ومنها ما خفي علينا؛ رعيا لمصالح العباد، ودرءً لمفاسدهم، تفضلاً لا وجوباً، وهي تنقسم إلى خمسة أقسام: والقسم الأول: شَرْعُ لكَسْر النفس، كالعبادات. (وهذا القسم راجع إلى حفظ الدين من جانب الوجود، كالإيمان، والنطق بالشهادتين، والصلاة، والزكاة، والصيام، والحجّ، وما أشبه ذلك). والقسم الثاني: شَرْعُ لبقاء جبلَّة الإنسان، كالإذن في المباحات المحصّلة للراحة، منَ: الطعام، واللباس، والمسكن، والوطء، وشبه ذلك. (وهذا القسم راجع إلى حفظ النفس والعقل والنسل من جانب الوجود أيضاً، كتناول المأكولات، والمشروبات، والملبوسات، والمسكونات، والمنكوحات، والمركوبات الجوالب للأقوات، وغيرها مما تمسنُ إليه الضرورات). والقسم الثالث: شَرْعُ لدفع الضرورات، كالبيوعات، والإجارات، والقراض، والمساقاة؛ لافتقار الإنسان ما ليس عنده من الأعيان، واحتياجه إلى استخدام غيره في تحصيل مصالحه. (وهذا القسم راجع إلى حفظ النفس والمال من جانب الوجود بوساطة هذه المعاملات الحاجيّة). والقسم الرابع: شَرْعُ تنبيهاً على مكارم الأخلاق، كالحض على المواساة، وعتق الرقاب، والهبات، والأحباس، والصدقات، ونحو ذلك من مكارم الأخلاق. (وهذا القسم راجع إلى حفظ النفس والمال وبتميلهما بوساطة هذه المعاملات التحسينيّة المفعمة بكمالات الآداب والمعاملات المزينة لمن تخلق بها مع عباد الله). والقسم الخامس: وهو المقصود من القضاء بالسياسة الشرعية، شَرْعُ للسياسة والزَّجْر، وهو ستة أصناف: الصنف الأول: شَرْعُ لصيانة الوجود، كالقصاص في النفوس والأطراف، (وهذا الصنف عائد إلى حفظ النفس من جانب العدم، وهو من الأمر بالمعروف والنهي عن المنكر .) والصنف الثاني: شَرٌٌْ لحفظ الأنساب، كحد الزّنا. (وهذا الصنف آيل إلى حفظ النسل من جانب العدم، كما بيناه في مراجعتنا لمصلحة حفظ النسب). والصنف الثالث: شرع لصيانة الأعراض؛ لأن صيانتها من أكبر الأغراض. (وهذا الصنف مندرج في باب النهي عن إذايات النفس والنسل،

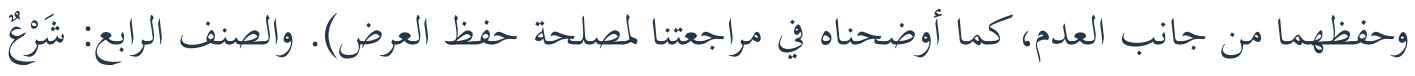
لصيانة الأموال كحد السرقة وحد الحرَابة. (وهذا الصنف راجع إلى حفظ المال من جانب العدم؛ وهو من

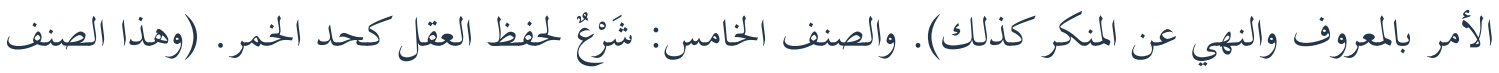
مرده إلى حفظ العقل من جانب العدم، وهو -أيضاً - من الأمر بالمعروف والنهي عن المنكر). والصنف لمرن 
السادس: شَرْعُ للردع والتعزير . (وهذا الصنف راجع إلى مكملات حفظ المصالح الحمس من جهة العدم؛ لأن التعزيرات مشروعة لدفع المفاسد التي ليس فيها قصاص ولا حد مقرر، وجامعه: الأمر بالمعروف، والنهي عن المنكر فيما تعلق بحقوق الله تعالى، أو بحقوق عباده، أو بالحقين معا). وهكذا، فكل ما ذكره ابن فرحون، لا يخرج عن دائرة المقاصد الضرورية الخمسة، فهو إما منها، أو خادم لها بكل ما من شأنه أن يوجدها ويبقي عليها في أحسن صورة، أو بكل ما من شأنه أن يقيها الإذاية، ويدفع عنها الضرر الواقع أو المتوقع. وخلاصة القول: إن كل ما أضافه قدماء أئمة فقه المقاصد إلى المقاصد الضرورية الخمسة، ليس منها عند التحقيق، وإنما هو إما من المقاصد الحاجية أو التحسينية الخادمة للمقاصد الضرورية بوجه من الوجوه.

\section{رابعاً: مجمل الإضافات المقاصدية الحديثة.}

من القضايا التي استأثرت باهتمام كثير من المهتمين بالفكر المقاصديّ الحديث قضية إعادة النظر في حصر المقاصد الضرورية في الخمسة المشهورة، وهو ما عبَّرَ عنه الأستاذ أحمد الريسوني بقوله: "فحصر الضروريات في هذه الخمسة، وإن كان قد حصل فيه ما يشبه الإجماع، يحتاج إلى إعادة النظر والمراجعة.... لأن هذا الحصر اجتهاديّ، وأن الزيادة على الخمس أمر وارد منذ القديم كما رأينا، ولا أريد الآن أن أقرر شيئا قبل أوانه وفي غير موضعه، ولكن أقول: لنفتح هذا الموضوع بموازين العلم وأدلته." وبجمل المقاصد التي أضافها علماؤنا المحدثون إلى المقاصد الخمسة لا تخرج عن: حفظ الفطرة، والسماحة، والنظام، والمساواة، والحرية، والعدالة، والكرامة، والحق، والأمن، والوحدة، والأخلاق، والسلام، والتعاون، والتعارف، وما إلى ذلك من القيم التكريمية الرفيعة، وهو ما يمكن الوقوف عليه فيما كتبه أمثال: ابن عاشور، وعلال الفاسي، وطه عبد الرمن، وأحمد الريسوني، وجمال الدين عطية. وكل هذه الإضافات لا خلاف في كوها مقاصد شرعية معتبرة ذات أهمية بالغة في حفظ نظام الشريعة ومصالح الناس، وإنما الخلاف فيما أشرنا إليه من "إشكال" فيما قبل، وهو: هل الإضافات المذكورة مقاصد ضروريّة فعلاً أم لا؟ فهذا هو جوهر الإشكال ولِّبُُّ الذي نواصل بتحديد النظر فيه ونحن نستحضر ما جاء في ماهية المقاصد الضرورية وأدلتها ومعاييرها، فنقول: إن اعتبار هذا المقصد أو ذاك مقصد شرعيّ ضروريّ، أو حاجيّ، أو تحسينيّ ليس مسألة رغبة ذاتيّة، أو ميل شخصي، ولا 
مسألة تَشَِّّ أو استجابةٍ عاطفيةٍ متسرعةٍ لضغوطاتٍ ما، ولا مسألة تظاهرٍ بالاجتهاد والإتيان بالجديد كيفما اتفق.! بل هي مسألة بحثٍ علميٍّ محرَّرٍ بقواعده ولوازمه الضرورية المقرَّرَة بينَ أهله. وعليه، فإنّ الاعتراضَ على حصر المقاصد الضرورية في الخمسة المشهورة، والدعوة إلى الزيادة فيها لا بد أن تستند إلى ما استند إليه القول بـ "مبدأ الحصر الخماسي" من الأدلة، أو إلى ما هو أقوى منه إن أمكن، وإلا بقيت دعوى تفتقر إلى الدليل؛ لأن القول بالزيادة على الضروريات الخمس، يحتاج إلى كثير من التأمل والاستقراء المستفيض لمصادر الشريعة ومواردها، والنظر في الواقع وبحاري العادات، ومراجعة ما قاله أهل العلم بشأها. وهو مالم أقف عليه في الأدبيات المعاصرة الداعية إلى بحاوز "مبدأ الحصر الخماسي!" فإذا نظرنا في الأدبيات المقاصدية الحديثة وجدنا فيها ثلاثة اتجاهات أساسية في النظر إلى المقاصد الضرورية: الاتحاه الأول: يمثله ابن عاشور، وعلال الفاسي. والاتجاه الثاني: يعبّرُ عنه أحمد الريسوني وطه عبد الرحمن وبمال الدين عطية. والاتحاه الثالث: لطه جابر العلواني، وهو صاحب "نظرية المقاصد الشرعية العليا الحاكمة" القائلة بخفض مقاصد الشريعة إلى ثلاثة، وهي: التوحيد، والتزكية، والعمران، بدل الزيادة فيها. وتفصيل هذه الاتجاهات فيما يأتي.

1. 1 وجهة نظر ابن عاشور وعلال الفاسي

فقد ذهب ابن عاشور وعلال الفاسي إلى القول بتوسيع دائرة المقاصد الشرعية، ومواكبة الاجتهاد فيها بما يوافق مقاصد الشارع، ويحقق مصالح الأمة، لكنهما لم يقولا بإعادة النظر في "مبدأ الحصر الخماسيّ" للمقاصد الضرورية، أما ابن عاشور فقد أطال النَّفَسَ في استخلاص و تأصيل مجموعة مقاصد شرعية، ذات دلالات وأبعاد مصلحية حضارية في حفظ نظام الشريعة ومصالح الأمة والإنسانية جمعاء، أهمها: حفظ الفطرة، والسماحة، والنظام، والمساواة، والحرية، وحقوق الناس. لكنه لمُ يُضْف عليها صفةَ "الضروريّة"، سواء بالمعنى المتداول في هذا الكتاب، أو بالمعنى الذي تفرد به في تعريفها، إذْ قال:" فالمصالح الضروريّة: هي التي تكون الأمة بمجموعها وآحادها في ضرورة إلى تحصيلها بحيث لا يستقيم النظام باختلالها، فإذا انخرمتْ تؤول حالة الأمة إلى فسادٍ وتلاشٍ. ولستُ أعني باختلال نظام الأمة هلاكها واضمحلالها؛ لأن هذا قد سلمت منه أعرق الأمم في الوثنيّة والهمجيّة، ولكني أعني أن تصير أحوال الأمة شبيهة بأحوال الأنعام بحيث لا تكون على الحالة التي أرادها الشارع منها." والمصالح الضروريّة المعنيّة هي المقاصد الخمسسة، بدليل قوله: "وقد مَثَّلَ 
الغزالئٌ في المستصفى، وابن الحاجب، والقرافي، والشاطبيّ هذا القسم الضروريّ ب: حفظ الدين، والنفوس، والعقول، والأموال، والأنساب ل...

والحق أن تعريف إمام الزيتونة ينطبق على مجموع المقاصد الحاجيّة الصّرفة، أو المنزَزَّة منزلةً الضروريّة بالخصوص، فهي التي متى اختلَّتْ بإطلاقِ صارتْ حياةُ الأمة شبيهةً بحياة الأنعام. أما المقاصد الضروريّة الخمسة فلا؛ لأهما إذا انخرمت لا تقف أحوال البشرية عند حلِّ معيَّنٍ من الفساد، بل تنجر إلى الفَنَاء العامّ، وهو ما أوضحناه في ماهية هذه المقاصد ومعاييرها. وأما الأستاذ الفاسي فلم يختلفْ كثيراً عن ابن عاشور في القول بحفظ مقاصد: الفطرة، والسلام، والكرامة، والمساواة، والعدل، والأخلاق، وحقوق الإنسان أيضاً. ولم يُضْف مثله صفة "الضرورية" على ما دونه من مقاصد؛ لتكون قريبة من أذهان المعاصرين بعد طول اشتغال بالموضوع وتَرَيُّثٍ في التدوين على حَدّ تعبيره." وهكذا فجميع ما أضافه الإمام ابن عاشور والأستاذ الفاسي لا يمكن عَدُّهُ من المقاصد الضروريّة، فالفطرة:

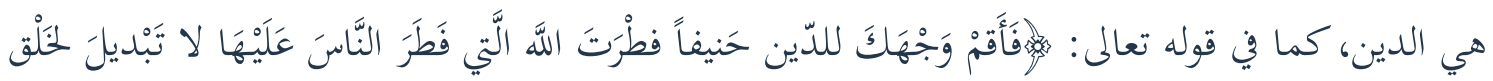

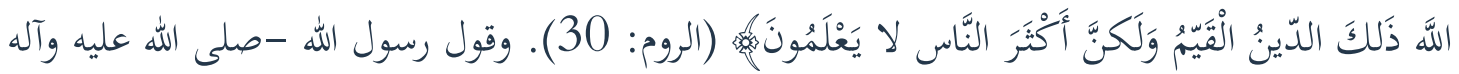
وسلم--:" كل مولود يولد على الفطرة، فأبواه يُهَوَّدانه، أو يُنَصَّرَانه، أو يُمَجِّسَانه...." والفطرة هنا هي

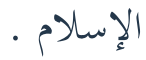

وأما فقدان الحرية، أو غياب العدالة، أو انعدام المساواة، أو شيوع التحارب، أو هضم حقوق العباد، أو بجزئة البلاد، وغير ذلك من المفاسد العامة والمظالم الشاملة فإن أقصى ما تنتهي إليه الحياة الإنسانية من جَرَّاء وقوعها أن يعيش الناس معيشة مليئة بالمعاناة البالغة، والمشاق الفادحة، والعسر المضني على جميع المستويات،

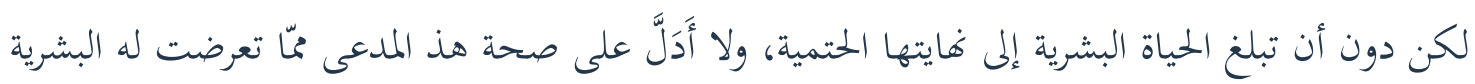
على امتداد وجودها التاريخي إلى اليوم من: انتكاسات، وانحرافات، وأزمات، وانتهاكات، ومظالم، ومعاناة على جميع المستويات: النفسية، والاجتماعية، والاقتصادية، والسياسية، وغيرها. ورغم كل ذلك فما زالت تتعايش مع مختلف آلامها ومآسيها، ولم يلحقها فَنَاءٌ منذ آلاف السنين، وهذا بخلاف ما لو فقدت المقاصد الضرورية الخمسة، فتلك فاية التاريخ وفَنَاءُ العالمَ. والله أعلم. 2 2. وجهة نظر الريسوني وطه عبد الرحمن وجمال الدين عطية: 
اتفق أصحاب هذا الاتحاه على "دعوى الزيادة" على الضروريّات الخمس، لكنهم اختلفوا في نظرقم إليها، فمنهم من دعا إلى إعادة النظر في "مبدأ الحصر الخماسي" للمقاصد الضرورية، كالأستاذ أحمد الريسوني، ومنهم من سَسجّلَ ما ظهر له من اعتراضات على هذا المبدأ، كالأستاذ طه عبد الرحمن، ومنهم من قَدََّّم محاولةً نظريةً تطبيقةً لمراجعة ذلك المبدأ من أصله، كالأستاذ جمال الدين عطية. أما الأستاذ الريسوني فقد اكتفى بالدعوة والتذكير ب"إعادة النظر في حصر الضروريات في الخمس المعروفة بدعوى أها مسألة اجتهادية.. وأنها ذات هيبة، ولا ينبغي أن خرم من منزلتها مقاصد أخرى لا تقل أهمية وشمولية عنها، وألمح إلى ما دعا إليه الأستاذ أحمد الخمليشي من جعل العدل وحقوق الفرد ضمن الضروريات من مقاصد الشريعة..." وإذا كان الأستاذ الفاضل لم يقرر شيئا في الموضوع إلى اليوم فهو مبدئيا من المنتصرين إلى"دعوى الزيادة" على الضروريات الخمس ما دامت مسألة " الخصر الخماسي "للمقاصد الضرورية من موارد الاجتهاد بالأساس وهذا مما لا مشاحة فيه؛ " لأن السابق وإن كان له حق الوضع والتأسيس والتأصيل، فللمتأخر الناقد حق التتميم والتكميل." غير أن الاحتجاج بقابلية المسألة للاجتهاد ليس دليلاً كافياً للإقناع بفتح باب الزيادة في المصالح الضرورية حتى يشفع بما يكفي من الأدلة القاطعة بمشروعية تلك الزيادة، وإلا بقي مجرد دعوى بغير دليل، ومعلوم أن "الدعوى المجردة غير مقبولة باتفاق العلماء."

وقد سألت أستاذنا أكثر من مرة عن رأيه في "دعوى الزيادة" فأَكَّدَ لي انتصاره لما، وأهم ما يراه جديراً بالإضافة إلى المقاصد الضرورية "مقصد الأخلاق"؛ لارقان الأمم بها وجوداً وعدماً، كما قال أحمد شوقي:

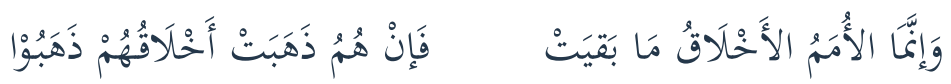
وهذا مّّا لا خلاف فيه، غير أنه لا جديد فيه بالنظر إلى حقيقة الأخلاق في التصور الإسلامي. فالخلق بضم اللام وسكوها في لسان العرب هو: الدين. وكذلك هي مكارم الأخلاق في شريعة الإسلام. لأن البعثة النبوية محصورة في إكمال حُسْن الأخلاق وصَالحها ومكارمها بالاستقراء، كما قال رسول الله صلى الله عليه وسلم: "بعثت لأتم حسن الأخلاق." و"إنما بعثت لأتمم صالح الأخلاق." و "إنما بعثت لأتمم مكارم الأخلاق." ومن المعلوم أن أعظم ما في البعثة النبوية: القرآن الكريم. وهو جامع الدين على الإطلاق. كما

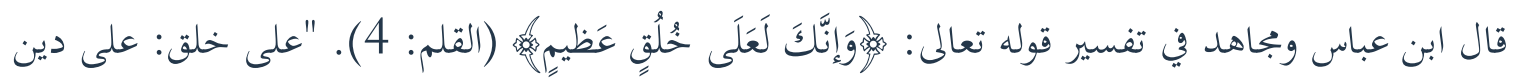
عظيم من الأديان. ليس دين أحب إلى الله تعالى ولا أرضى عنه منه." "وأيضا فإن ما ذكر في القرآن من 
مكارم الأخلاق، كان خلق رسول الله صلى الله عليه وسلم." وهو ما أخبرت به السيدة عائشة رضي الله عنها؛ عندما سئلت عن خلق رسول الله صلى الله عليه وسلم، فقالت: "كان خلقه القرآن." واقتصرت في خلقه على ذلك. فدل على أن قوله وفعله وتقريره راجع إلى القرآن. لأن الخلق محصور في هذه الأشياء، ولأن الله جعل القرآن تبيانا لكل شيء." ومن المعلوم "أن القرآن هو كلية الشريعة، وهو على اختصاره جامع، ولا

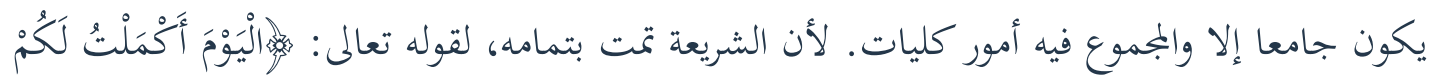
دينَكُمْهُه. (المائدة: 3). فإذا نظرنا إلى رجوع الشريعة إلى كلياتها المعنوية وجدناها قد تضمنها القرآن على لى الكمال وهي: الضروريّات، والحاجيّات، والتحسينيّات، ومُكَمّل كلّ واحدٍ منها." وهذه النظرة القرآنية الكلية إلى "مقصد الأخلاق" وشموليته لجميع مناحي الحياة الخاصة والعامة تؤكد بأن أخلاق الشريعة غير مصورة في مرتبة المقاصد التحسينية، و"إنما هي نظام متكامل لحياة شاملة، نظام يُوَجِّهُ

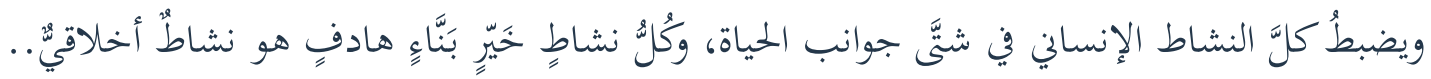
والنيةُ عنصرٌ أصيلٌ، في تقويم كلّ نشاطٍ. والقرآن لا يمثل فضائل متناثرة وَحسنب، ولكنه يعرض ويفرض نظاماً كاملاً شاملاً للحياة البشرية، تدخل فيه عمارة الأرض، والعلاقات السياسية والاقتصادية والاجتماعية والدولية، كما يدخل فيه تنظيم الحياة النفسية والعقلية والجسدية على أسس من شرع الله، وهذا على وجه الإجمال هو مدلول مصطلح الأخلاق في الإسلام "؛ لأن " الشريعة كلها إنما هي تَََلُقٌُ بمكارم الأخلاق "... وبناءً على هذه القاعدة ف"لا يصح أن تكون البعثة المحمدية منحصرة في تتميم أوصاف زائدة على ما هو ضروريّ وحاجيّ، بحيث لا يقدح تركها إلا فيمن ادعى العدل أو الشهادة أو الولاية. والحق أن مكارم الأخلاق شاملة لكل المصالح التي تضمنتها الشريعة المطهرة،" وبهذا تسقط كل الدعاوى القائلة بحصر الأخلاق في نطاق ضيق من مقاصد الشريعة، هو قسم التحسينيّات دون سواه، كما يقول بعض الأصوليين، أو بإقصائها كليةً، كما ذهب إلى ذلك بعض المهحدَثَنَ، يأتي في مقدمتهم الأستاذ محمد عابد الجابري. وبهذا نخلص إلى" أن الدين والأخلاق شيء واحد، فلا دين بغير أخلاق، ولا أخلاق بغير دين." ولا دين غير

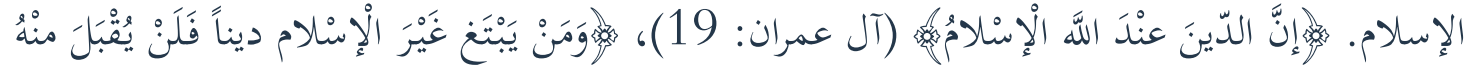

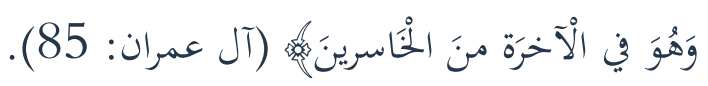
وأما الأستاذ طه عبد الرحمن فقد أورد اعتراضاتٍ منهجيةً مختلفةً، عامّة وخاصّة على تقسيم القيم الشرعية 
وترتيبها بصفة عامة، وقد نص على ذلك في مقال له بعنوان:" مشروع بتحيد علمي لمبحث مقاصد الشريعة." فهو يرى أن تقسيم الأصوليين للقيم إلى ثلاثة أقسام، وترتيبها على ثلاث درجات: ضرورية، وحاجيّة، وتحسينّة، يخُّلُ بشرط التباين من شروط التقسيم، حيث إن القيم التي يتكون منها القسم الضروريّ، مثل: الدين، والنفس، والعقل، والنسل، والمال، لا يستقل بهذا التقسيم، بل يشاركه فيها القسمان الآخران: الحاجيّ والتحسينيّ، ومثاله: الأحكام الثلاثة المتعلقة بتحريم الزنا الذي يعد حكماً يحقق قيمةً ضروريّة، وتحريم النظر إلى عورة المرأة الذي يعد حكماً يحقق قيمة حاجيّةً، وتحريم تَبَرُج المرأة الذي يعد حكماً يحقق قيمةً تحسينية، تشترك كلها في حفظ النسل. إن الاعتراض الخاص الوارد على القيم الضرورية هو أها تخل بشروط التقسيم، فثمة إخلال بشرط تمام الحصر: فقد اشتهر حصر الأصوليين لهذه القيم في خمس مستقرأة، وهي: حفظ الدين، وحفظ النفس، وحفظ العقل، وحفظ النسل، وحفظ المال، والحال أنه لا يمتنع إدخال قيم أخرى فيه، مثل: "حفظ العرض"، و"حفظ العدل"، و"حفظ الذكر"، و"حفظ الحرية"، و"حفظ التكافل"، وغيرها مما يقتضيه تقلب الأطوار الإنسانية في العيش. وثمة إخلال بشرط التباين: فإن القيمة الواحدة من هذه القيم لا تباين ما سواها من القيم، فلا حفظ للمال بغير حفظ العقل، فيكون العقل جزءاً من المال، ولا حفظ للعقل بغير حفظ النسل، فيكون النسل جزءاً من العقل، ولا حفظ للنسل بغير حفظ النفس، فتكون النفس جزءاً من النسل، ولا حفظ للنفس بغير حفظ الدين، فيكون الدين جزءاً من النفس. وثمة إخلال بشرط التخصيص: فليست كل قيمة من هذه القيم أخص من الأصل المحصور الذي هو الشريعة، فحفظ الدين الذي اعتبر قيمة من قيم الشريعة هو كذلك مساو للشريعة؛ فتدخل تحته القيم الأخرى؛ ولا ينفع أن يقال بأن المراد بالدين في هذا التقسيم هو الاعتقادات والعبادات، فهذا تخصيص بغير دليل؛ لأن الأحكام التي تراعي حفظ القيم الأخرى هي -أيضاً- أحكام تراعي حفظ الدين . وجميع هذه الاعتراضات سبق للدكتور طه عبد الرحمن أن أورد مثلها مع بعض الاختلافات الطفيفة في كتابه "تحديد المنهج في تقويم التراث" تحت عنوان: "قلق التقسيم الأصولي للمصالح." وعند مراجعتنا لهذه الاعتراضات نجد أن. الاعتراض العام على تقسيم القيم الشرعية وترتيبها اعتراض غير صحيح؛ لأن اندراج الأحكام المتعلقة بالقيم الحاجيّة والتحسينيّة تحت الأجناس الخمسة لا يقدح في انفراد القيم الضروريّة بهذه 
الأجناس؛ لأنّ القيم الضرورية الخمس هي القاعدة الأصليّة، وكل ما سواها من القيم الحاجيّة والتحسينيّة تابع لها، وحائمُ حولَ حمَاهَا بالخدمة والتقوية والتجميل، وهو ما جعل قيمة تحريم النظر إلى عورة المرأة، وهي قيمة حاجيّة، أو قيمة تحريم تبرُّج المرأة، وهي قيمة تحسينيّة، كلاهما يدخل في قيمة حفظ النسل، وهي قيمة ضروريّة، وَقسن على ذلك جميع القيم الحاجيّة أو التحسينيّة في علاقتها بالقيم الضروريّة؛ لأن "كل حاجيّ وتحسينيّ إنما هو خادم للأصل الضروريّ، ومُمْْنسٌُ به، ومحسّنُ لصورته الخاصة، إما مقدمةً له، أو مقارناً أو تابعاً، وعلى كل تقدير فهو يدور بالخدمة حواليه، فهو أحرى أن يتأدى به الضروريّ على أحسن حالاته. فأنت ترى أن المكمّلات الدائرة حول حمى الضروريّ، خادمة له ومقوية لجانبه، فلو خلت عن ذلك أو عن أكثره لكان خللا فيها، وعلى هذا الترتيب تجري سائر الضروريات مع مكملاتما لمن اعتبرها؛ لأنه إذا كان الضروريّ قد يختل باختلال هُكمّلاته كانت المحافظة عليها لأجله مطلوبة، ولأنه إذا كانت زينة لا يظهر حسنه إلا بها كان من الأحق أن لا يخل بها." وهو ما يقطع بضرورة العناية بجميع القيم الشرعية الضرورية والحاجية والتحسينية، على ما بينها من تفاوت في الاعتبار، وتفاضل في الترتيب، وتكامل في الحفظ، لكن مع الحرص على تنزيل القيم الضرورية الخمس فوق كل ما سواها من مراتب القيم. أما الاعتراض الأول من الاعتراضات الخاصة بالقيم الضرورية فمردودٌ بلمنطق نفسه؛ لأن "حفظ العرض، والعدل، والذكر، والحرية، والتكافل" وما في معناها من الإضافات المقاصدية القديمة والحديثة غير مستوفية شرط تمام الدخول ضمن القيم الضرورية؛ لأن فقدان هذه القيم وأمثالها لا يترتب عنه فقدان الحياة بالمرة كما يترتب عن فقدان القيم الضرورية الخمس، بل أقصى ما يترتب عن فقداها انتشارُ العَنَت والعُسرُ، وإصابة المكلَّنينَ بالحَرج والمشقَّة والضّيق، وهو ما بينَّاهُ بالتفصيل في مراجعتنا للإضافات المقاصدية السابقة. وأما الاعتراض الثاني فلا حجة فيه؛ لأن توقف كل قيمة من القيم الخمس على ما سواها من القيم من الأمور المعلومة، كما قال الإمام الشاطبي: "إن مصالح الدين والدنيا مبنية على المحافظة على الأمور الحمسة... فإذا اعتبر قيام هذا الوجود الدنيوي مَبْنًَّاً عليها حتى إذا الخخرت لمُ يبق للدنيا وجود -أعني ما هو خاصٌٌ بالمكلَّنينَ والتكليف- وكذلك الأمور الأخروية لا قيام ها إلا بذلك، فلو عُدمَ الدّينُ عُدمَ ترتُّبُ الجزاء

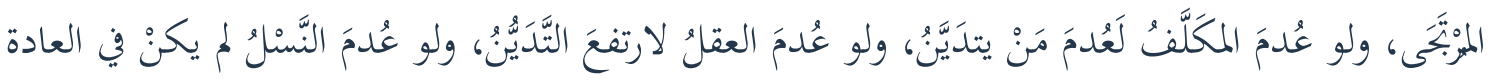

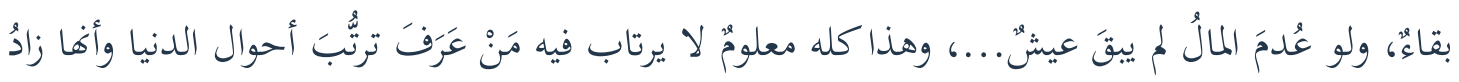


الآخرة." وهذا التلازم الوجودي بين مصالح الدنيا والآخرة والمحافظة على القيم الضرورية الخمس؛ لا يعني أن هذه القيم غير متباينة الأجناس فيما بينها في واقع الأمر، وإلا كانت كلها قيمةً واحدةً، وهي ليست قيمةً واحدةً، وهو ما يخالف مقررات الشريعة، ويناقض منطق الواقع الملموس، فكما هو معلوم أن الدين شيء؛، والنَّْْسَ شيءُ آخرُ، وكذلك باقي المقاصد كلٌٌ منها مستقلٌّ بذاته مباينُ لغيره، وما اختلاف أحكام وجزاءات القيام، أو الإخلال بهذه القيم إلا دليل على تباينها وتفاضل مراتبها، وإلا فلماذا تباينت أحكامها واختلفت جزاءاتها إذا كانت غير متباينة في أجناسها ابتداء؟! ويكفي أن نسوق فاقد العقل مثالاً، فهو نفسُ، وإن كان لا عقل له، ولو كان حفظ العقل غير مباين لحفظ النفس لانعدمت النفس بانعدام العقل كما ينعدم العقل بانعدام النفس، وهو ما يقطع ببطلان الاعتراض المذكور أعلاه. وأما الاعتراض الثالث فصحيح أن الدين ليس أخص من الشريعة - كباقي المقاصد الأخرى-؛ لتساويهما، لكن عدم التخصيص هنا لا يلزم عنه حصر مقاصد الشريعة في أربعة فقط؛ لأن ما اصطلح عليها بمقاصد الشريعة هي في أصلها مقاصد الشارع الحكيم من التشريع، ومعلوم أن حفظ الدين/ (الشريعة) هو أول مقاصد الشارع، وهنا لا بجال للقول بالتخصيص؛ إذ لا مساواة بين المشرع -سبحانه- والشريعة، وبهذا الاعتبار فلا مُشَاََََّة في الاصطلاح؛ ولذلك فلا معنى لهذا الاعتراض أيضاً. أما د.جمال الدين عطية، فقد تناول " مبدأ الحصر الخماسيّ " بالمراجعة، وانتهى إلى القول: "ونحن من جانبنا نأخذ بعدم انحصار الكليات من حيث المبدأ ومن حيث التطبيق... حيث أضفنا العديد من المقاصد فبلغت أربعة وعشرين بدلا من خمسة... موزعة على أربعة مجالات، وهي: مجال الفرد، وبجال الأسرة، ومجال الأمة، ومجال الإنسانية." ولمعرفة وجه الصواب في هذه الدعوى نعرض أولاً ما نَصَّ عليه الأستاذ الفاضل من ججالات، وما تضمنته من مقاصد، فمجال الفرد تضمَّنَ خمسةَ مقاصدَ، وهي: حفظ النفس، والعقل، رَّلَ والدين، والعرْض، والمال، ومجال الأسرة تضمَّنَ سبعة مقاصد، وهي: تنظيم العلاقات بين الجنسين، وحفظ النسل (النوع)، وتحقيق السكن والمودة والرحة، وحفظ النسب، وحفظ التدين في الأسرة، وتنظيم الجانب المؤسسي للأسرة، وتنظيم الجانب المالي للأسرة، وبجال الأمة تضمن سبعة مقاصد، وهي: التنظيم المؤسسي للأمة، وحفظ الأمن، وإقامة العدل، وحفظ الدين والأخلاق، والتعاون والتضامن والتكافل، ونشر العلم وحفظ عقل الأمة، وعمارة الأرض، وحفظ ثروة الأمة، وبجال الإنسانية تضمن خمسة مقاصد، وهي: 
التعارف والتعاون والتكامل، وتحقيق الخلافة العامة للإنسان في الأرض، وتحقيق السلام العالمي على أساس العدل، والحماية الدولية لحقوق الإنسان، ونشر دعوة الإسلام .

وهذا التصنيف والتوزيع المقاصدي الذي فجه الأستاذ عطية يعبّرُ عن نظرة اجتهادية متقدمة في التنزيل المقاصديّ على مختلف المجالات الحيوية المستهدفة بالخطاب الشرعي المفعم برعاية المصالح الإنسانية على جميع المستويات الخاصة والعامة. ومع تقديرنا لهذا الجههد العلمي المتميز، فإننا لا نوافق أستاذنا على إدراج جميع المقاصد المذكورة أعلاه في مسمى المقاصد الضرورية؛ لأها تفتقر كلها إلى الدليل العلمي، إذ منها: الضروري العيني، مثثلا في المقاصد: حفظ النفس، والعقل والدين والمال من بجال الفرد. و حفظ النسل، وحفظ التدين من مجال الأسرة. و حفظ الدين و الأخلاق من مجال الأمة. والضروري الكفائي، ممثلا في المقصد: التنظيم المؤسسي من مجال الأمة. والحاجي العيني، مثثلا في المقاصد: حفظ العرض من مجال الفرد. وحفظ النسب من مجال الأسرة. وحفظ الأمن واقامة العدل من مجال الأمة. وتحقيق السلام العالمي على اساس العدل، والحماية الدولية الحقوق الانسان من بجال الإنسانية. والمركب المتداخل بين الحاجي والتحسيني الكفائين، ممثلاً في المقاصد: تنظيم العلاقات بين الجنسين، وتحقيق السكن والمودة والرحمة، وتنظيم الجانب المؤسسي للأسرة، وتنظيم الجانب الملالي لها، من بجال الأسرة. والمركب المتداخل بين الضروري والحاجي والتحسيني العيني، ممثلا في المقصدين: عمارة الارض وحفظ ثروة الأمة، من مجال الأمة. والمركب المتداخل بين الحاجي الكفائي والتحسيني العيني، ممثلا في المقاصد: التعاون والتضامن والتكامل من بجال الأمة. و والتعارف والتعاون والتكامل، وتحقيق الخلافة العامة للانسان في الأرض، ونشر دعوة الإسلام من ججال

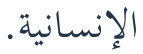

وللتدقيق، نخص كل بجموعة من هذه المجموعات الست بالتوضيح والمراجعة فيما يأتي: فالمجموعة الأولى: تدخل كلها في دائرة المقاصد الضرورية الخمسة، وإن تنوعت تعبيرات الأستاذ عطية عن بعضها، كالمقاصد: حفظ الدين من مجال الفرد. وحفظ التدين من ججال الأسرة. و حفظ الدين والأخلاق

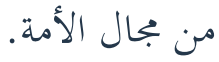
أما المجموعة الثانية: فتضم مقصداً واحداً، وهو التنظيم المؤسسي للأمة، وهذا المقصد من المقاصد الشرعية الكفائية الموضوعة لتنظيم المصالح العامة ومايتها، وهي من هذا الوجه مكملة للمقاصد الشرعية الضرورية 
العينية أساساً، ولاحقة بها في كوغا ضرورية، إذْ لا تقوم المقاصد العينية إلا بالكفائية؛ وذلك أن المقاصد الكفائية قيام بمصالح عامة لجميع الخلق . ونظراً لأهمية المقاصد الكفائية في تنظيم العمران وتدبير الشأن العام، وحفظ المصالح الخاصة، وحماية المصالح العامة فقد أولاها الإمام الشاطبيّ عنايةً خاصّة، وركَّزَ فيها على كيفية تحقيق المقاصد الكفائية، وتولي الولايات العامة، وضرورة إسنادها لمن يستحقها من الخبراء وذوي الكفاءات العالية، ووجوب التفكير في رسم خطة علمية عملية؛ لتربية النبغاء والمتفوقين من طلبة العلم، والعناية بالعناصر المتميزة بالفطنة والذكاء، والسهر على تكوينها حتى يتخرج كل منها فيما يناسبه من التخصصات والمهام المطلوبة في مختلف مجالات تسيير وتدبير شؤون الدولة ومؤسساها، كما هو واضح من كلام أبي إسحاق و تأصيلاته الرائعة لمختلف المصالح العامة في المسألة الحادية عشرة من كتاب الأحكام . وبكذا التصور المتكامل لرعاية مصالح الجماعة يكون الإمام الشاطبي قد خطا خطوات متقدمة في الاهتمام بمصالح الأمة إلى جانب اهتمامه بمصالح أفرادها، وهو ما اعتمده الأستاذ عطية بتصرف طفيف في تأصيل قراءته المعاصرة لفروض الكفاية، أي: لمقاصد الجماعة، إذ قال: "كتب الإمام الشاطبي -وهو بصدد وضع التصور العملي لممارسة فروض الكفاية- إن مواهب الناس مختلفة، وقدراتم في الأمور متباينة ومتفاوتة، فهذا قد هَيأ للعلم، وهذا للإدارة والرئاسة، وذلك للصناعة أو الزراعة، وهذا للصراع، والواجب أنْ يُرَبَّ كلُّ امريئٍ على ما عَيَّاُ له؛ حتى يبرز كل واحد فيما غلب عليه ومال إليه.. وبذلك يُرََّّ لكلّ فعل هو فرض كفاية قوم، ويتبين أن تحقيق الفروض الكفائية واجب على الجميع، وكل بقدر ما تقيئه له قدرته، فالقادر عليه أن يقوم بالعمل بالفعل، وغير القادر عليه أن يمكن القادر، وبذلك يكون تحقيق العمل قد وقع من الجميع في الجملة. إن مثل هذا التخطيط الجماعي لتحقيق غرض جماعي، ولرفع إثم جماعي، لا يككن تصوره إلا في جماعة موحدة الفكر والشعور، وهذا ما نفتقده في عالم الإسلام اليوم، وما ينبغي أن خرص عليه كبداية للطريق ". وعليه، فما الجلديد في كلام الأستاذ عطية عن فروض الكفاية (مقاصد الجماعة) غير ما أَصَّلَهُ وَفَصَّلَهُ الإمام الشاطبيُّ في موافقاته منذ قرون؟! وكيف جاز له أن يقول في حديثه عن مسألة حصر المقاصد الضرورية في خمسة: "ولكن الشاطبي وقف عند هذا الحد، ولم يتابع الفكرة حتى فايتها بتحديد مقاصد للجماعة إلى جانب مقاصد الفرد." وهو لمُ يجد غير كلام الشاطبي ليعضد رأيه في الموضوع، فأي تناقض هذا؟! وعلى كلٍ 
فإن "من الإبانة عزو الفوائد إلى أهلها، ونسبتها إلى السابقين إليها،" فذلك من بركة العلم ومقتضياته. و تأسيساً على ما سبق فإن كل المقاصد الكفائية تبقى خادمة للمقاصد الضرورية الخمسة، وحافظة لها من بن جانبي: الوجود، والعدم؛ لأها لا تقوم في الواقع إلا بها، فلو فرضنا انعدام المقاصد الضرورية الخمسةلم يعد للمقاصد الكفائية أي اعتبار، بل ولا وجود أصلا؛ لأن المقاصد الكفائية كما أفا مقاصد فهي وسائل أيضاً. ومعلوم أن الوسائل بمقاصدها، ومن ثم فهي غير مقصودة لذاتا، وإنما هي تبع للمقاصد في أحكامها، تقوم

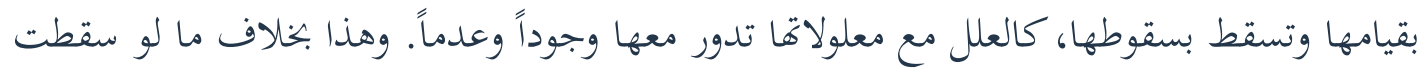
الوسائل الكفائية، فإن المقاصد الضرورية العينية الخمسة، قد تختل بوجه ما، لكن لا تبلغ مبلغ السقوط الكلي التام، وهو ما يقطع بأصالتها، وانتصاب كل ما سواها من المقاصد لخدمتها من جميع جوانبها، إذ هي

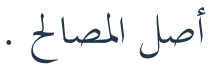

وبالجملة، فالمقاصد الكفائية كلها وسائل لجلب مصالح المقاصد الضرورية العينية الخمسة، ودفع المفاسد الواقعة أو المتوقعة عنها؛ لأن " الوسائل لا تراد لذواتما وإنما المراد غاياتما التي هي المقاصد ". ومن تأمل المقاصد الضرورية الخمسة في علاقتها العملية بجميع المقاصد الكفائية وجدها لا تخرج عن هذا الترتيب. وأما المجموعة الثالثة: فمنها ما سبق برهان تصنيفه في مرتبة الحاجيات الخادمة لمصلحة حفظ النسل، كالعرض والنسب، وهو ما قرره الأستاذ عطية في ختام حديثه عن حفظ العرُض، إذْ قال: " ونخن نوافق ابن عاشور على عَدّه في الحاجيّات في مجال الفرد فيما يخص المساس بالجانب الجنسيّ، أما فيما يخص المساس بباقي جوانب كرامة الإنسان، فأعتبره من التحسينيّات". فإذا كانت هذه مرتبة العرض في نظر أستاذنا، فكيف عَدَّهُ من الضروريَّات، وهو ليس منها باعترافه، أليس في هذا نوع إيهامٍ وتناقضٍ؟؟ ومنها ما هو مندرج في قسم الحاجيات المنزلة منزلة الضروريات؛ لمسيس الحاجة العامة إليه، كحفظ الأمن والعدل في بجال الأمة. وتحقيق السلام العالمي العادل، والحماية الدولية لحقوق الإنسان في مجال الإنسانية، إذ مهما انعدم الأمن، وضاع العدل، وانتشرت الحروب، وانتهكت الحقوق الإنسانية، فإنّ حياة الناس لا تنعدم بإطلاق، كما لو انعدمت المقاصد الضرورية الخمسة كلها أو بعضها، كما بيناه من قبل؛ ولذلك فلا معنى لعَدّ المقاصد المذكورة ضمن الضروريات، وهي ليست منها.

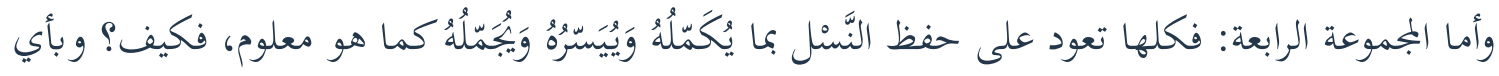




$$
\text { مقياس انتقل أستاذنا بما هو من الحاجيّات والتحسينيّات إلى الضروريّات؟! }
$$

وأما المجموعة الخامسة: فلقد كفانا الأستاذ عطية مراجعتها، إذْ أقرَّ بتداخل الضروريّ والحاجيّ والتحسينيّ في كلا المقصدين الواردين فيها، فقال في غاية كلامه عن المقصد السادس من بجال الأمة: "وفي كل من هذه المراحل هناك ما يعتبر من الضروريّات وما يعتبر من الحاجيّات وما يعتبر من التحسينيّات." كما قال في متم حديثه عن المقصد السابع من المجال نفسه: وفي كل هذه المجالات ما يتعلق بالضروريّات والحاجيّات، كما فيها ما يتعلق بالتحسينيّات ".

فإذا كانت هذه حقيقة المجموعة الخامسة، فبأي معيار أدرجت في مرتبة الضروريات بإطلاق؟ أليس في هذا إخلال بمقتضيات الدقة العلمية المطلوبة في تحديد المراتب المقاصدية، وتمييز بعضها عن بعض كما هو معهود

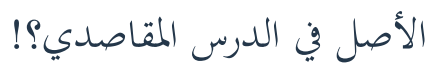

وأما المجموعة السادسة: فمدارها على المقاصد الضرورية الخمسة بالخدمة والتوسعة والتزيين والترفيه. ومن راجعها وجدها كما وصفناها. وإذا ثبت هذا الوصف؛ فبأي دليل تم وضعها ضمن المقاصد الضرورية؟ وبهذا تبقى المقاصد الضرورية الخمسة القاعدة الأساسيّة، وكلٌُ ما سواها من المقاصد الكفائية دائرة في فلكها؛ بحيث لو شغر الوجود عن كل ماعدا الضروريات الخمس، فإن أقصى ما يقع: اختلال نظام الحياة البشرية اختلالا بليغا، واضطرابه اضطرابا كبيرا، يعود بها إلى أدنى مستويات البدائية، لكن دون أن يصل بها إلى درجة الفناء المطلق، إذ قد مرت الإنسانية بمراحل -وما زال بعضها يمر بها في كثير من أنحاء العالم إلى اليومافتقرت فيها لأبسط وسائل العيش مع شيوع الججهل، وسيطرة عقلية التغلب؛ ومنطق التوحش، ومع ذلك لم

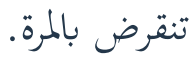
وقد تقرر فيما سبق أن ما لا تنعدم الحياة البشرية وتتعطل مرافقها ومصالحها كلها بانعدامه مطلقا، لا يعد في مرتبة المقاصد الضرورية، وإنما يعد إما في أرقى مراتب المقاصد الحاجية المنزلة منزلة المقاصد الضرورية لفرط الحاجة العامة إليها، أو في متوسط الحاجيّات، أو في أدناها، حتى ينتهي إلى مرتبة التحسينيّات والكماليّات التي تتأدّى بها الضروريّات على أحسن الحالات، ولا يضير فقداها المقاصد الضرورية إلا بوجه ما ـ

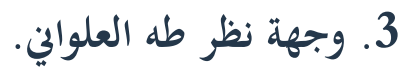

أما الاتحاه الثالث فقد ذهب مذهباً مغايراً للاتحاهين السابقين، إذْ خَفَّضَ مقاصد الشريعة إلى ثلاثة مقاصد 
أساسية فقط، بدل أن يزيدَ فيها، وَيُعَدُّ الأستاذ العلواني خير من عَبَّرَ عن هذا الاتحاه من المعاصرين. فقد أسس الأستاذ العلواينّ لـ" نظرية المقاصد الشرعية العليا الحاكمة " في كتابه" مقاصد الشريعة " وَعَدَّها كلياتٍ مطلقةً قطعيةً، تنحصر مصادرها في الاستقراء التام لمحكمات الكتاب العزيز، وصحيح السنة النبوية، وما تلقته العقول بالقَبُول، وحَدَّدَهَا في ثلاثة مقاصد أساسية، وهي: التوحيد، والتزكية، والعمران. ووصفها بالمشتركات الرسالية المندرجة تحت مفهوم (العبادة) بشكل تام .

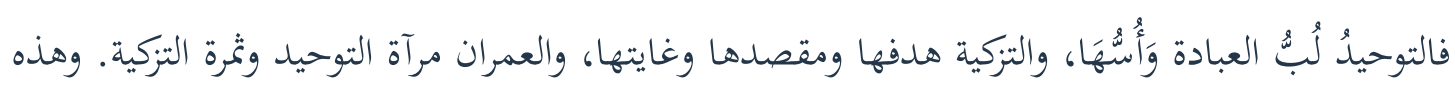
المقاصد الثلاثة العليا تستدعي -بالضرورة- سائر المستويات الأخرى من المقاصد (كالعدل، والحرية، والمساواة)، كما تستدعي ما جرى تركيز الأصوليين والفقهاء عليه من مقاصد الشريعة، فصنفوها إلى: الضروريّات الإنسانيّة، والحاجيّات، والتحسينيّات، وهي - في نظر الأستاذ العلواني- لمُ تستطعْ أنْ تقدّمَ أوْ تُوَلِّدَ منظومة الأحكام التي نتماجها لتغطية ومعالجة كل مستجدات الحياة التي سيتعلق بها الفعل الإنساني حتى يوم الدين، بل اكتفت بأن بينت لنا حكم الشريعة والتشريع، وفوائدها التي تعود على ضروريّاتنا وحاجيّاتنا وتحسينيّاتنا بالحفظ والتسديد والحماية، فهي في وضعها الذي حَلَّدوهُ ابتداءً من إمام الحرمين الجويني، ثم الغزالي، مروراً بالشاطبي، ثم ابن تيمية، وابن القيم، وإلى الشيخين علال الفاسي، وابن عاشور،

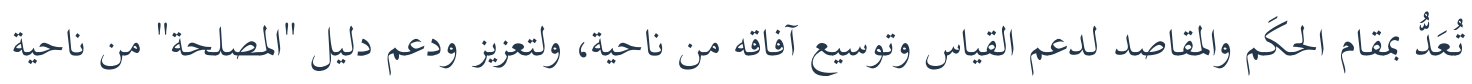
أخرى، وكذلك لتعزيز الإيمان والثقة برعاية الأحكام الشرعية لمصالح العباد...!" فهذه خلاصة وجهة نظر الأستاذ العلواني في مقاصد الشريعة، وفي مراجعتها نقول -بإيجاٍٍٍ - إن ثلاثية: التوحيد، والتزكية، والعمران لا خلاف في كوها من مقاصد الشريعة، ولا في أهميتها ودورها الكبير في تأطير وتنظيم الحياة الخاصة والعامة للإنسان على جميع المستويات، ويف كل المجالات، وهو ما بَيَّنَهُ صاحب هذه النظرية في المراجع المشار إليها في الهامش أدناه، إلا أنه لا يمكن التسليم بقيامها مقام المقاصد الضرورية الخمسة، ولا بأن تكون بديلاً عنها أو مستوعبةً لها، فضلا عن أن تكون أصلا لها، إذْ يستحيل أنْ يقومَ الجزئئُ مقامَ الكليّ، ولا أنْ يُعَدَََّ عليه، أو يكونَ مستوعباً له، بل العكس هو الصحيح . فمقصد التوحيد، أو الإيمان، أو العقيدة هو شطر مقصد الدين، كما هو معلوم بالاستقراء التام، ومقصد التزكية أو التربية ثمرة مقصد الدين؛ إذ لا تزكية بدون دين، ومقصد العمران أو الاجتماع البشري هو غاية 
المقاصد الضرورية الخمسة ونتاجها؛ إذ لا عمران بدوفها أصلاً. وهكذا، فالتوحيد مقصد من مقاصد الدين ومندرج فيه، ولا يمكن أن يخرج عنه، والتزكية مقصد آخر من مقاصد الدين، ولا تتم إلا به، ولا تنفصل عنه في التصور الإسلامي، والعمران مقصد ثالث من مقاصد الدين، ولا يقوم إلا على أساس مقاصده الضرورية

وبهذا يظهر أن كل مقاصد الشريعة تنطلق من المقاصد الخمسة وترجع إليها؛ ولذلك قلنا: إنه متى وُجدَتْ

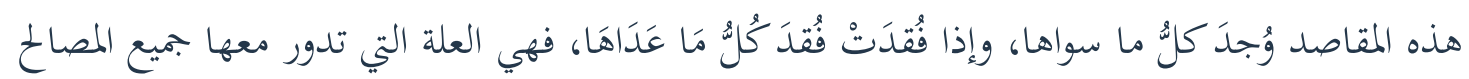
الدنيوية والأخروية وجوداً وعدماً، كما مَرَّ مُفَصَّلاً، وهو ما يقطع بثبات المقاصد الخمسة واستيعاهما لكل شيء باعتبارها حقوقاً إنسانيةً عامةً تخترقُ الحدودَ الإقليميّة والخصوصيّات البشريّة على امتداد الوجود التاريخيّ للبشر، إذْ مُ تخلُ أمة من الأمم ولا ملة من الملل من اعتبارها، والتشديد عليها، والعمل على لى إصلاحها، وإنْ وَقَعَ التهاونُ في بعض جوانبها من حينٍ إلى آخر هنا وهناك.

لكنْ مُم يُعْلَمْ أن قوماً كُتبَ لهم البقاء مع انعدام تلك المقاصد أو بعضها، بينما استمرت شعوب وقبائل وبجتمعات وأمم في غياب التوحيد، وشيوع الشرك بمختلف صنوفه، وتراجع التزكية، وانتشار التدسية، وفساد الاجتماع البشريّ، وفوضى العمران، وهو ما يشهد به واقع البشرية اليوم في أكثر من مكان. وإذا صحت هذه المراجعة النقدية العامة صََّّ "مبدأ الحَصْر الخماسيّ" وبطلت "دعوى التغيُّر" بالزيادة على المقاصد الضرورية الخمسة، أو بالنقصان منها، ومَنْ زاولَ مقاصدَ الشريعة تأكَََّتْ لديه هذه الحقيقة. وفي هذا القَدْر كفايةُ بيانٍ ودلالةٍ على ضرورة العناية اللازمة بجميع المقاصد الشرعية، لكن مع إعطاء الأولوية في الاعتبار والمحافظة للمقاصد الضرورية الخمسة التي "تأتي في مقدمة جميع المقاصد باعتبارها مقاصدَكونيةً عالميةً، لا تخلو منها ملة من الملل، ولا حقبة من حقَب التاريخ الإنسانيّ، فهي بمنزلة الثوابت المبطَّردة، والقيَم الخالدة التي بها قوام الاجتماع الإنساني وقيامُهُ، والتي عليها مدار العمران البشريّ وبها انتظامُهُ، ومعنى ذلك

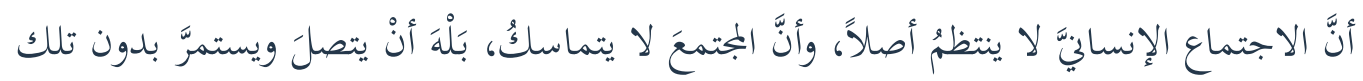
الضروريّات أو الكُليّّات الخمس." و والله أعلم. 